\title{
Searching for Franklin where he was ordered to go: Captain Erasmus Ommanney's sledging campaign to Cape Walker and beyond, spring 1851
}

\author{
W. Barr \\ Arctic Institute of North America, University of Calgary, 2500 University Drive NW, Calgary AB \\ T2N 1N4, Canada (circumpolarbill@gmail.com)
}

Received January 2016; first published online 6 April 2016

ABSTRACT. Since the Admiralty's instructions to Captain Sir John Franklin for his attempt at a transit of the northwest passage in HMS Erebus and Terror in 1845 specified that he should proceed to Cape Walker at the northeastern tip of Russell Island, and head southwest from there to the waterways already explored along the mainland coast of North America, as far as ice conditions and any intervening land permitted, it was natural that the first search expedition to come within striking distance of Cape Walker, should make this one of the starting points of its detailed search. This was the squadron of Captain Horatio Austin that wintered off the northeast coast of Griffith Island in 1850-1851. Following his orders, in the spring of 1851 Captain Erasmus Ommanney of HMS Assistance set off with an impressive cavalcade of seven man-hauled sledges, most of them support sledges. From Cape Walker Lt. William Browne searched the east coast of Prince of Wales Island, that is the western shores of Peel Sound while Ommanney himself and Lt. Sherard Osborn searched the west coast of Prince of Wales Island, that is the east shore of McClintock Channel. No traces of Franklin's expedition were found. Their conclusions were that both McClintock Channel and Peel Sound were permanently blocked with ice, and that Franklin's ships could not have travelled south by either route. While the conclusion as regards McClintock Channel was absolutely correct, that with regard to Peel Sound was incorrect. This must have been the route whereby Erebus and Terror had reached the vicinity of King William Island, and the conclusion that Peel Sound never cleared of ice was very unfortunate in that the next search expedition dispatched by the Admiralty, that of Captain Sir Edward Belcher in 1852-1854 made no attempt to penetrate south, when it is possible that Peel Sound was clear of ice.

\section{Introduction}

The instructions that the Lords Commissioners of the Admiralty issued to Captain Sir John Franklin with regard to his anticipated attempt at making a transit of the northwest passage in HMS Erebus and Terror, starting in 1845 , were quite specific. He was directed to reach Lancaster Sound via Baffin Bay and from there:

... in proceeding to the westward .... You will not stop to examine any openings either to the northward or southward in [Barrow] Strait, but continue to push to the westward without loss of time, in the latitude of about $74^{\circ}$, till you have reached the longitude of that portion of land on which Cape Walker is situated, or about $98^{\circ}$ west. From that point we desire that every effort be used to endeavour to penetrate to the southward and westward in a course as direct towards Bhering's Strait as the position and extent of the ice, or the existence of land, at present unknown, may admit (Great Britain 1848a: 4).

Cape Walker was the most westerly point seen by Captain William Edward Parry on the south shores of what has since been named Parry Channel during his recordbreaking westward penetration in HMS Hecla and Griper in the summer of 1819 (Parry 1821). He later saw parts of Banks Island from Cape Dundas on Melville Island, but only across the impassable ice of M'Clure Strait, whereas he had seen Cape Walker across open water, or at least sailing ice.

Given the instructions which Franklin had received, one would perhaps have expected that the first expedition dispatched by the Admiralty to search for the missing expedition from the east would have been directed to start its search from Cape Walker. This was Sir James Clark Ross's expedition on board HMS Enterprise and Investigator, which sailed from England in 1848 (Ross 1994). And indeed Ross was directed that 'The several intervals of coast that appear in our charts to lie between Cape Clarence [the northeast tip of Somerset Island] and Cape Walker, must next be carefully explored' (Great Britain 1848b: 1). Captain Edward Bird of HMS Investigator was specifically ordered to attempt to winter near Cape Rennell, the northernmost tip of Somerset Island [but then believed to be the north end of Boothia Peninsula]. From there, in the spring of 1849 , he was ordered to search the west coast of Boothia Peninsula, (that is Somerset Island),

while another party may proceed to the southward, and ascertain whether the blank space shown there in our charts consists of an open sea through which Sir John Franklin may have passed or, on the contrary, if a continuous chain of Islands, among which he may still be blocked up (Great Britain 1848b: 1).

Thereby Ross and/or Bird was being directed to the 'blank space' south and west of Cape Walker, a 'blank space clearly delimited in the map in Cyriax (1939).

In the event Ross encountered 'a heavy body of ice extending from the west of Cornwallis Island in a compact mass to Leopold Island ... we had difficulty in keeping the ships free during the nights, for I believe so great a quantity of ice was never before seen in Barrow's Strait 
at this period of the season' (Ross 1850: 59). In fact it was only with considerable difficulty, that he managed to reach Port Leopold at the northeastern tip of Somerset Island with both ships and there settled down for the winter. In May 1849 Ross sledged west to Cape Bunny but from there "we obtained a very extensive view, and observed that the whole space between it and Cape Walker to the west ... was occupied by very heavy hummocky ice, whilst to the southward it appeared more favourable for travelling' (Ross 1850: 61). He therefore headed south, surveying most of the west coast of Somerset Island. Cape Bunny was thus the closest he came to Cape Walker.

In 1850 the Admiralty dispatched six ships to continue the search: HMS Lady Franklin and Sophia under the command of Captain William Penny and HMS Resolute and Assistance and the steam tenders Pioneer and Intrepid, under the overall command of Captain Horatio Austin. Austin sailed on board HMS Resolute, while Assistance was commanded by Captain Erasmus Ommanney, Intrepid by Lieutenant John Bertie Cator, and Pioneer by Lieutenant Sherard Osborn. Austin's instructions were that he should 'use every exertion to reach Melville Island, detaching a portion of your ships to search the shores of Wellington Channel and the coast about Cape Walker, to which point Sir J. Franklin was ordered to proceed' (Great Britain 1850: 5).

Having successfully entered Lancaster Sound the squadron reached Beechey Island near which, on 23 August 1850 Ommanney discovered the first traces of the Franklin expedition at Cape Riley, namely circles of stones which had held down a number of tents, and a scattering of artefacts, including, most significantly some empty tins which had contained Donkin's preserved meats (Ommanney 1850-1851). Later in the day he also found the first indications that Franklin's ships had wintered across the bay at Beechey Island, including a length of rope partly buried in the beach gravel.

Thereafter, heading west, Austin's ships were temporarily beset for several weeks, first in southern Wellington Channel, then off the south coast of Cornwallis Island, but ultimately all four ships became solidly beset, about half a mile apart and about 1 mile $(1.6 \mathrm{~km})$ off the northeast coast of Griffith Island by 25 September 1850 (Ommanney 1850-1851). But before this, on 11 September, Ommanney, in Intrepid, steamed south to try to reach Cape Walker, but heavy snow, poor visibility (less than half a mile $(0.8 \mathrm{~km})$ ) and close ice, brought the steamer to a halt only a few miles off Cape Bunny (Ommanney 1850-1851). Austin and his captains were quite apprehensive as to the possibility of ice pressures in their wintering location, but, fortunately, if largely by accident, they had become embedded in the fast ice off the shores of Griffith Island, and were not seriously threatened by ice movements during the winter (Fig. 1).

In the autumn several reconnaissance sledge trips were undertaken in preparation for the spring sledging campaign. Thus on 2 October Lieutenant Leopold McClintock, accompanied by Dr. Abraham Bradford set off to establish a depot towards Melville Island, while Lt. Robert Aldrich headed for Somerville and Lowther islands (Ommanney 1850-1851; Osborn 1852a: 110). McClintock was halted by blizzard conditions and landed his depot on southwestern Cornwallis Island on 8 October (Ommanney 1850-1851). Over the period 10-12 October, Osborn surveyed a section of the south coast of Cornwallis Island (Osborn 1852a: 112-117).

Thereafter the squadron settled down to what was already becoming the standard routine for an arctic wintering by Royal Navy ships: it involved a period of regular daily exercise, the housing in of the upper decks, theatricals and other entertainments, Guy Fawkes celebrations on 5 November, publication of a newspaper, in this case the Illustrated Arctic News, and school-lessons for the men. With the four ships lying so close together there was much visiting from ship to ship, while Griffith Island was frequently the destination for officers taking exercise.

Two other expeditions were wintering in relatively close proximity to Griffith Island, namely at Assistance Harbour on southern Cornwallis Island. These were Penny's expedition in Lady Franklin and Sophia (Sutherland 1852) and that of the arctic veteran Captain John Ross in Felix (Ross 1994; Wilson 1973). In view of the proximity of the two wintering parties, there was some degree of visiting to and fro between them. News of where these other ships were wintering was brought to Austin's squadron on 8 October by Lt. George Mecham who had discovered them while surveying the south coast of Cornwallis Island. On 17 October Penny arrived at Griffith Island for a brief visit. On the following evening he met Austin and Ommanney to discuss the plans for spring searches; it was decided that Penny would search Wellington Channel and the northern parts of the islands lying on the north side of Parry Channel, while parties from Austin's squadron would search west to Melville Island and south to Cape Walker and beyond (Ommanney 1850-1851). Then on 18 February 1851 Dr. Bradford and Mate Richard Vesey Hamilton set off for Assistance Harbour to visit 'the neighbours' (Ommanney 1850 1851). They returned on 24 February, accompanied by Penny, Captain Alexander Stewart of Sophia, Dr. Robert Goodsir of Lady Franklin, and John Stuart, third mate of that vessel. A few days later, on 27 February, several of Ross's officers from Felix arrived: Captain Charles Philipps, Dr. David Porteous and Thomas Abernethy (2nd mate) (Ommanney 1850-1851).

\section{The sledging programme}

On 10 March a meeting was held of all the officers of Austin's squadron who had been selected to lead spring sledging parties. Ommanney was to take command of the largest division consisting of six main sledges and an auxiliary, bound for Cape Walker and beyond. The following month was spent in preparations, including regular hikes across the ice for all sledge crews, for example to Cape Martyr on Cornwallis Island and back, 


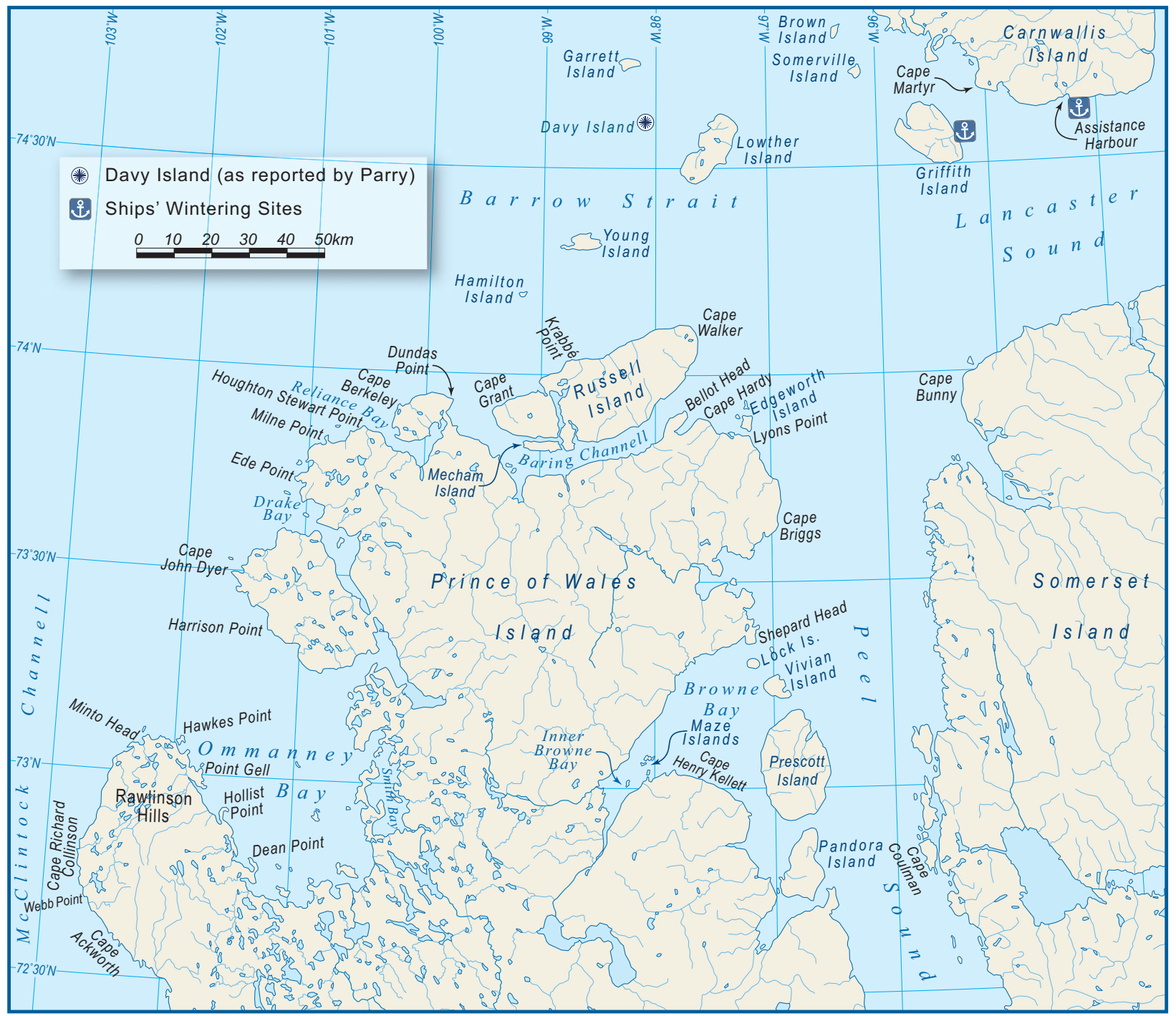

Fig. 1. The area searched by Ommanney and his team.

a round trip of 12 miles $(19.3 \mathrm{~km})$. Next the sledge parties practiced hauling their sledges full of gravel from Griffith Island; this was destined for ballast for the ships, which were now relatively light. Then on 12 April all the sledges were hauled to a starting point off the north end of Griffith Island. This involved an impressive cavalcade of 14 sledges each led by an officer and hauled by 6 or 7 men (Osborn 1852a: 155-156). From this assembly point five sledges led by McClintock would head west to Winter Harbour on Melville Island and beyond. These were McClintock's own sledge and that of Dr. Abraham Bradford, plus three support sledges which would transport depots to intermediate points, namely those of $\mathrm{Mr}$. Walter May (mate), Mr. William Shellabear (2nd mate) and Mr. John Cheyne (mate). Two more sledges were to head north via Byam Martin Channel, namely those of Lt. Robert Aldrich and Mr. Richard Pearse (mate). Ommanney's own division, bound southwest to Cape Walker and beyond, consisted of seven sledges; these were his own sledge (Reliance) and that of Lt. Sherard Osborn, commanding Pioneer (True Blue) and five support sledges, namely those of Lt. George Mecham, Third Lieutenant on board Assistance (Succour), Lt. William Browne, Second Lieutenant on board Resolute (Enterprize), Mr. Richard Vesey Hamilton, Mate on board Assistance (Adventure), Mr. Charles Ede, Assistant surgeon on board Assistance (Inflexible), and Mr. Frederick Krabbé, Second Master on board Assistance (Success). Each sledge had its own motto and flag.

Ommanney's division (and possibly also McClintock's and Aldrich's) was accompanied by a single small dog sledge, pulled by one dog. The dogs were gifts from Penny (Osborn 1852a). There is no mention in any of the accounts of who drove these dogs, but presumably somebody had been allocated this duty.

At the assembly point each sledge party pitched its tent, spread its ground-sheet and sleeping bags, and prepared and ate lunch, that is that it conducted a trial of what would soon be the daily routine. Then the tents were struck, sledges packed, and, except for a rear-guard left to keep an eye on the sledges, everyone returned to the ships. Bad weather then caused a delay but on the 
evening of 15 April all the sledge parties, totalling 90 men and 14 officers set off back to the waiting sledges (Ommanney 1852: 31). They left the ships at 6.30 p.m. to the cheers of those staying behind and were accompanied by Captain Austin and a few of the remaining officers. Despite a gale of wind and falling snow they reached the sledges at 10 p.m. and tents were pitched. Those who had been left in charge of the sledges prepared tea and grog (diluted rum) for each man. Austin then read a prayer and made a short speech. Then, to more cheers, all 14 sledges set off, Ommanney's division westwards along the north coast of Griffith Island and McClintock's and Aldrich's divisions northwards toward the coast of Cornwallis Island.

\section{Heading south to Cape Walker}

Ommanney's own sledge, Reliance, (with the motto 'Domine dirige nos' [Guide us, O Lord]) was hauled by six men: William Dore (Captain of the main-top); Frederick Brooke (Captain's coxswain); Charles Campbell (Cooper), Edward Privett (A.B.), Thomas Ward (A.B.) and George Davis (A.B.). Despite their earlier practice at hauling ballast for the ships the men found it hard going: they were negotiating sastrugi ridges in wind and falling snow. After only 5 miles $(8 \mathrm{~km})$ they pitched camp at 2 a.m. on 16 April near the northwest tip of Griffith Island; after drinking some tea the men were in their blanket bags by 4 a.m., but had difficulty in sleeping due to the novelty of the situation.

The cooks were roused out at 3 p.m.; each officer then read a prayer; and tea and cold pemmican were served. After a quick check of all seven sledge parties the medical officer (Dr. Charles Ede) reported all in good health. By 6 p.m. the train of seven sledges was on its way, heading southwest. Thus the pattern of sleeping during the day and travelling at night, was established right from the start. By this time of year, of course, the sun was above the horizon for most of the 24 hours.

Although the extensive fields of sastrugi made progress laborious, worse was to come. At 9 p.m. they encountered a belt of chaotic pressure-ice extending from Griffith Island towards Somerville Island, with deep snow in the intervening hollows; the men even had recourse to levelling some hummocks and removing ice projections with pickaxes to make any progress. They even had to resort to double-manning occasionally (Mecham 1852a: 53). Fortunately, after an hour's strenuous work they reached more level ice again. In what would become standard practice, the tents were pitched for lunch, to prevent the men from becoming seriously chilled while waiting for snow to be melted to dilute their grog. Lunch consisted of cold salt pork, biscuit and a half allowance of grog. Progress was slow, not only because of the rough pressure ice, but because of snow and drifting snow which reduced visibility to a quarter of a mile $(0.4 \mathrm{~km})$ and often much less (Browne 1852: 65). By 3.30 a.m. when the division camped for the night the men were exhausted and Ommanney himself admitted to being 'very tired myself' (Ommanney 1852: 31).

The convoy of sledges advanced slowly southwestwards, usually for 7 to 9 hours per day, with an hour or so for lunch, and covering a distance of 8 to 12 miles (12.8$18.2 \mathrm{~km})$. The sledges travelled in single file with the lead sledge being changed every half hour, to reduce the strain on the eyes of the lead sledge-crew, especially its leader, 'the eye becoming speedily wearied and incapable of detecting the ridges or raised portions of the floe (Ede 1852: 76) in the prevailing whiteout conditions. Two officers usually scouted ahead of the lead sledge to select the best route, especially among hummocks. During the march of 18-19 April the crews suffered greatly from thirst, and despite the admonitions of the officers were constantly eating snow (Osborn 1852b: 90). As Dr. Ede remarked 'The men appear to enjoy a cup of tea even more than their grog at supper' (Ede 1852: 76).

By the time they pitched camp in the early hours of 19 April Cape Walker was in sight, bearing N. $6^{\circ}$ E. (magnetic), but only 'very indistinct, the weather being hazy' (Browne 1852: 66). It should be borne in mind that since the North Magnetic Pole lay somewhere to the eastsoutheast on Somerset Island (variation $153^{\circ} \mathrm{W}$ ), this bearing of Cape Walker was about SW (true).

At 9 p.m. on 19 April some seals were seen on the ice and a group of officers including Hamilton, went in pursuit of them but, vigilant as always. the seals slipped down their holes long before they got close or even within rifle range; the thickness of the ice was found to be 36 inches $(90 \mathrm{~cm})$ (Osborn 1852b: 90). With a rise in temperature to $+30^{\circ} \mathrm{F}\left(-1^{\circ} \mathrm{C}\right)$, and with level ice the sledges made 10 miles $(16 \mathrm{~km})$ during their fifth march, despite the men suffering from thirst. Ommanney has described them as 'working merrily' (Ommanney 1852: 32).

Navigation on the morning of $20^{\text {th }}$ April was very difficult:

Found great difficulty in making a straight course, the weather being very thick, not an object being visible on the sublime but dreary waste of snow, the sky harmonizing with the gloom of the floe, being of an uniform sombre hue overhead, while round the horizon a purplish cloud edged with misty streaks completely blending sky and snow. This strange effect was very tedious on the eyes, especially those of the leaders, who were frequently compelled to turn round and gaze on the dark forms composing our little caravan, thereby trying to afford some relief to their straining eyes (Browne 1852: 66).

On the afternoon of the 20 April one of the first signs of spring was spotted: a small flock of snow buntings (Pectrophenax nivalis) flying north (Ede 1852: 77). By that evening Cape Walker appeared so close that there were even hopes of reaching it before camping. The men were encouraged in this idea by their first attempt at hoisting sails on the sledges since there was a strong 
wind from right aft. The sails were the rubberized 'floorcloths', that is the ground-sheets for the tents, and the masts were the pikes used as tent-poles. They were so effective that in the case of some of the sledges the number of men hauling could be reduced from six to two (Hamilton 1852: 105). And this was despite the snow being quite deep. Ommanney (1852: 33) described the sledges as 'scudding along like a fleet of junks'. Browne (1852:66) was reminded 'at a little distance of a fleet of Malay proas, with their dark sails of mat, the snow drift appearing like foam on the water in a fresh breeze.' An attempt was also made at using kites but they were found to be less effective, 'the speed of the sledges slacking the lines which caused them to fall' (Ommanney 1852: 33), 'but in justice to them, it must be said the wind was not steady but in squalls' (Ede 1852: 77).

Forced to face reality Ommanney and his men were obliged to camp for one more 'night'; a drop in temperature to $-5^{\circ} \mathrm{F}\left(-20.5^{\circ} \mathrm{C}\right)$ gave them little sleep however. When they started again (at 7.30 p.m. on the 21 April) the view of the impressive sandstone cliffs of Cape Walker was enhanced by a spectacular parhelia, described in vivid detail by Osborn (1852b: 91). Some of the men were suffering from frost-bitten faces, and a halt had to be made so that those still wearing leather sea-boots could change into canvas boots.

To reach the beach at the foot of the cliffs the sledge crews had to overcome a final obstacle: a belt of massive pressure ridges. To negotiate it some of the sledges were partially unloaded and all of them were double-manned for a short distance, once a passable route had been achieved by using pickaxes. There were even some treacherous snow-covered cracks and Ommanney had the misfortune to fall through and got a foot wet. Nonetheless, at midnight he was able to order the Union Flag hoisted on the beach.

The tents were pitched on the beach, although it was rather rough, and the ground solidly frozen. By then the temperature had dropped to $-15^{\circ} \mathrm{F}\left(-26^{\circ} \mathrm{C}\right)$, and the men were ordered into their blanket bags. In the early hours of 22 May Dr. Ede 'was sent for to see a man belonging to the True Blue (Thomas Marshall), who had both his feet severely frost-bitten. Instead of changing his boots as desired, after the day's march, he remained outside the tent cooking, and when he removed his boots to turn in, found his feet in the state mentioned' (Ede 1852: 77). Ede recommended that he return to the ships immediately. There were also other less serious cases of frostbite, including W. Baily, R.M., of Mecham's crew.

\section{Reconnaissance of the Cape Walker area}

The point where they had landed lay slightly west of the extreme northeast tip of Cape Walker (and of its highest cliffs). Ommanney now sent a party off in each direction to search for any signs that Franklin's expedition might have landed here, a very reasonable expectation given the emphasis on Cape Walker in Franklin's orders. Browne, Ede and a five-man party headed east round the end of the cape and then some distance southwards; Mecham and Hamilton were sent westwards.

Browne and Ede returned at 10 p.m.; several of this party had developed frostbite and hence they had been forced to turn back after only 4 miles $(6.4 \mathrm{~km})$. Ede's report includes a detailed description of the appearance and geological composition of the terrain below the cliffs, namely:

We proceeded along the shore, which consists of the debris of the cliffs heaped up into irregular terraces by the action of the ice, and varying in depth, from the base of cliff to the floe edge, from 200 to 500 yards. The nature of the stone is conglomerate or 'pudding-stone', with which the beach is strewed. Immense masses rent by the action of frost lying in every direction. The composition of the masses found in the debris and the debris itself was that of limestone and greenstone, united by red sandstone, the pieces of the former being rounded and smooth. This kind of structure obtained as far as we proceeded to the S.E. (Ede 1852: 78).

Beyond the high eastern end of the cape they had swung south. Browne reported an 'extensive low plain' to the south; the visibility was very poor, however, with drifting snow and what he was seeing was in fact the entrance to Baring Channel separating Russell Island from Prince of Wales Island. He could also make out some high land to the southeast 'but only for a few moments, on account of the thickness of the weather' (Browne 1852: 67); this in fact was the prominent Bellot Head. He also reported seeing some old Inuit houses and some Arctic hares and snow buntings, even a dead, frozen snow bunting. Mecham and Hamilton returned some time after midnight, having advanced some 6 miles (9.6 $\mathrm{km})$ to the west-southwest and having twice climbed hills to get a better view of the coast; they reported the coast continuing in this direction and becoming steadily lower. Neither party had seen any sign of the Franklin expedition.

Hot soup was served at 2 a.m. on 23 April (Ommanney 1852: 34$)$, then everyone returned to the sleeping bags and even managed to get some sleep despite the wind and the cold. At noon Ommanney recorded: 'Found the gale not abated; thermometer $-15^{\circ}[\mathrm{F}$.]; miserable in tent; ran about on beach ice to get warm.' Having determined that the coast ran generally south from just east of Cape Walker Ommanney decided to send Browne to investigate this coast, that is the west shore of Peel Sound. Meanwhile Krabbé was ordered to get ready to return to the ships, taking the frostbitten Marshall with him. Thomas Armstrong was to take Marshall's place. In the evening of 23 April Ommanney took formal possession of the land in the name of Queen Victoria, the ceremony being accompanied by three cheers. 


\section{Krabbé returns to the ships}

Then Krabbé set off on the morning of 23 April; Marshall 'was placed in a blanket bag, and enveloped in the wolfskin blankets, and laid in a couch on the sledge formed of tent, blanket bags and haversacks' (Ede 1852: 78). A party of men helped Krabbé's crew to negotiate the belt of pressure ice along the shore.

To compensate for the additional weight of Marshall on the sledge Krabbé joined his men in helping to haul the sledge. It was bitterly cold $\left(-26^{\circ} \mathrm{F}\left(-32^{\circ} \mathrm{C}\right)\right)$ with a strong wind, and Krabbé found that the grog (diluted rum) was frozen. At lunch time he found that four of his men, White, Custance, Hayden and M'Clean had frost-bitten feet, hands and faces, and in light of this he decided to stop until the weather improved. He and his men did not get going again until 1 a.m. on 25 April, and in view of this delay and the state of his men, he cut their rations by a third. Fortunately, when they did get moving again all the crew were fit to help haul the sledge, although 'two were doing but little' (Krabbé 1852a: 85) and once again he himself was helping to haul. Whenever possible he was following their outward-bound tracks. There was little let-up in the temperatures; at lunchtime on 26 April (7.20 a.m.) the temperature was $-17^{\circ} \mathrm{F}$ ($27^{\circ} \mathrm{C}$ ) resulting in many cases of frostbite on fingers and faces. While drinking their luncheon grog they 'found it become complete sludge in the pannikin' (Krabbé 1852a: 85 ), and when Krabbé tried to take a sun-shot at noon to determine his latitude he found that 'frost-bites too frequent on the hands to be able to perform that duty' (Krabbé1852a: 85).

Soon after midnight on 27 April a bear with her cub came to within 100 yards of the tent, but raced off when they saw men moving around the tent. When they set off after breakfast 'Heyden obliged to be put on the sleigh from crippled state of his feet, as well as Marshall' (Krabbé 1852a: 85). Once again Krabbé was 'on the drag-rope' along with his men. When they camped in the early afternoon, assessing the remaining distance to be covered, Krabbé decided to put his men on full food allowance again. By 7.30 on the morning of 28 April they were passing the northwest cape of Griffith Island. By mid-morning they were spotted from the ships and a party of officers met them and 'assisted at the drag-rope'. At noon a fatigue party arrived from the ships and took over from Krabbé's sledge crew entirely. The invalids were carried aboard their respective ships.

Krabbé and his men had covered a total distance of 120 nautical miles $(222 \mathrm{~km})$.

\section{Back at Cape Walker}

After the departure of Krabbé's sledge the main focus of the remaining combined party was building a cairn near the bottom of the cliffs, by a prominent rock towering near the entrance to a ravine. In it Ommanney deposited a record along with some coins. Here, too, two of Halkett's inflatable boats (see Note 1) were buried.
A year later another, independent expedition, that of Captain William Kennedy and Lieutenant de Vaisseau Joseph-René Bellot, visited Cape Walker on 4 May 1852, part way through their long sledge trip from their ship, Prince Albert, wintering at Batty Bay on the east coast of Somerset Island (Bellot 1854; Kennedy 1853; Barr and Forestier Blazarts 2014). Strangely, they failed to find Ommanney's cairn at the bottom of the cliffs, which rather surprised them, since they were aware that Austin's orders had been to proceed to Cape Walker and continue from there and had expected that some of his ships or sledge parties would have visited the cape.

For Ommanney and his men there was no let-up in the weather, however, and after midnight all the men were sent back to their sleeping bags. But this was only a relative improvement. Hamilton reported that the cold was so intense that, although in my bag, my chronometer, which was in an inside pocket, stopped, so that after this its only use was as a time-piece' (Hamilton 1852: 105), that is it could no longer be used for determining longitude. Nor was there any improvement on 24 April: 'The gale continued; the gusts off the high cliff rattling the tent about our ears. Cramped and tired with the confinement of the tent; went out occasionally to run about and obtain warmth; all equally miserable in the other tents. At 10h. enjoyed some hot soup' (Omanney 1852: 34). By 5.30 p.m. the weather had improved greatly, however; the temperature had risen to $-7^{\circ} \mathrm{F}\left(-21.7^{\circ} \mathrm{C}\right)$, and preparations began for getting under way again.

\section{Browne searches the east coast of Prince of Wales Island}

Lt. Browne's party received a 'top-up' of 5 days' provisions from Ede's sledge Inflexible. This of course was a mixed blessing, in that his sledge was now heavier than when he left the ships. To the cheers of the other sledge crews, at 8.45 p.m. Browne and his men, with the sledge Enterprize, set off southwards to explore and search the western shores of Peel Sound. Despite the heavy load on the sledge they made good progress, the men assisted by the sail once again. Beyond the south end of the Cape Walker cliffs Browne headed straight for the prominent headland of Bellot Head; in so doing he was unwittingly cutting across the eastern entrance to Baring Channel. They reached Bellot Head in the early hours of 26 April and Browne decided to leave a 10-day depot of provisions here, especially since 'the last day's journey proved too much for the crew' (Browne 1852: 68). After burying the depot, he and his crew camped for the 'night', but before going to sleep he had the crew make some modifications to the footwear: 'Employed the crew enlarging the canvas boots across the instep, so as to enable the men to wear more wrappers on their feet, also to facilitate putting the boots on when hard with the cold, many of the men having complained much the previous day' (Browne 1852: 68). In the early hours of the next day the mercury was frozen in the neck of Browne's 
thermometer, indicating a temperature at or close to $40^{\circ}$ (F. and C.). The party was now heading east towards Lyons Point (which Browne named East Cape), passing between Edgeworth Island and the mainland of Prince of Wales Island. After camping for one more 'night' they reached the cape around midnight; here Browne built a cairn and left a message. The coast of Somerset Island in the area of Cape Bunny was clearly visible across Peel Sound.

From this point the party was heading almost due south, and with a northwest wind were able to take advantage of the sail and very smooth ice to ease the strain on the men. By 4.30 a.m. on 29 April they had reached Cape Briggs, where they camped. When they woke at 6 p.m. in the evening the weather had cleared and Browne could see a series of islands stretching to the south and south east. But he decided to pursue his route along the mainland coast, leaving the exploration of these islands for his return journey. The party was now coasting around the shores of Back Bay.

Soon after they started the next march at 7.30 p.m. on 30 April they encountered a lead, 5 to 6 feet wide in many places, running for several mile out from shore. They had difficulty crossing it since the edges were 'very treacherous.' By lunch time at 3 a.m. on 1 May they could now discern that the islands to the southeast were one long one and several smaller one. Shortly after this they encountered another fairly wide lead which gave them some trouble; it occurred at the junction between the pack ice and the landfast ice.

In the early hours of 2 May the party reached the prominent headland of Sherard Head. There was a strong southerly wind blowing "with heavy drift right in our teeth', which gave rise to numerous cases of frostbite. Browne therefore decided to camp here, although they had been travelling for only 5 hours instead of the usual 10-11 hours. This was a prolonged storm, however, and it was not until 7.30 p.m. on 4 May that Browne decided to start moving again, although it was still very foggy. For much of the time during this enforced delay he was afraid that the tent would be blown down, but fortunately this did not happen; his understated comment, 'Very wretched in the confined tent' (Browne 1852: 69). Before leaving this campsite he left a message in a cairn.

As the party continued south they were following round the shores of the extensive embayment of Browne Bay. Browne describes one section as 'a low beach, extending two miles from the cliffs. A quantity of small vegetation, such as mosses, short grass and dwarf willow,... and also marks of hares and deer' (Browne 1852: 70). There was little improvement in the weather, however, and when another storm blew in with snow and drifting snow, it again kept the party weather-bound for 48 hours.

They were on the move again by 8 p.m. on 8 May, and when they stopped for lunch they "saw two deer (rein) of considerable size, of a cream colour, with dark saddle-shaped spots on their backs; they were very shy and soon made off' (Browne 1852: 70. They also saw two ptarmigan. A long island, extending north-south (Prescott Island) was visible to the east.

By lunchtime in the early hours of 10 May, they could see the coast to the south swinging east, and soon they were travelling in that direction. It is somewhat difficult to reconcile Browne's description and map with the reality of the geography. He writes of 'steering for the northern extremity of the eastern land'; this was possibly Cape Henry Kellett, but if so he had failed to realise that he had cross the mouth of Inner Browne Bay, and also the extensive labyrinth of the well-named Maze Islands.

By the evening of 11 May, however, the party was heading southeast aiming for the strait between Prescott Island to the north and Pandora Island to the south. With good, hard snow and a fair wind they set the sail on the sledge, greatly increasing their speed. A small bear was spotted in the distance, the only one sighted on the entire trip. By the following evening they had reached the narrows between the two islands. Browne noted: 'The extremities of both islands are composed of dark cliffs of considerable height, composed of granite, and interspersed with many ravines' (Browne 1852: 71). At lunchtime in the early hours of 13 May the party landed on the northern tip of Pandora Island; having decided to start back north from here, Browne had his men build a cairn in which he deposited a message. Visibility was good and Cape Coulman (named by James Clark Ross after his wife's family) on the coast of Somerset Island was clearly visible to the east.

A wolf approached the camp and was fired at and wounded but it managed to escape although two men gave chase. Browne's description is quite detailed: 'the animal appeared to be very thin, and was of a light grey colour, with considerable darkening near the muzzle and head, and about the size of a Newfoundland dog, only narrower in the chest; the print of his foot was very large, with the two middle toes projecting considerably beyond the others' (Browne 1852: 75).

Getting under way on the evening of 13 May, Browne had decided to follow the east coast of Prescott Island and the others north of it. He described the cliffs of Prescott Island as being composed of reddish granite and about 500 feet high. That night, sheltered by the cliffs, he described as the warmest they had spent on the trip. The party reached the northeastern tip of Prescott Island around midnight on 14/15 May and camped under the lee of the southeastern cliffs of Vivian Island. Soon after they got started on the evening of 15 May, they were passing the north end of Vivian Island, on a course back to Sherard Head.

Bypassing Lock Island, they reached Sherard Head in the early hours of 16 May; it is a high headland, joined to the mainland of Prince of Wales Island by a low isthmus, which now deceived Browne into thinking it was an island. Thereafter, heading north across Back Bay, aiming for Cape Briggs they experienced very warm weather 'indeed the warmest this season as yet', so much 
so that it was so warm in the tent during the day that the men slept on, rather than inside, their sleeping bags. They passed Cape Briggs soon after midnight on 18 May.

Passing Cape Lyons they swung across to Edgeworth Island and searched its east and north shores. They camped on its north coast at 5.30 a.m. on 19 May, but were then weather-bound during a northwesterly gale with heavy drifting snow until 6 p.m. on 22 May. Browne assessed it as the worst weather they had encountered thus far, noting that 'To give some idea of the drift, I will only state that frequently the sledge could barely be discerned from the tent door, although only about five yards distant' (Browne 1852: 72).

Getting under way on the evening of 22 May, they had reached Bellot Head by 2.30 next morning, and spent the next few hours digging up the depot and reorganising the provisions on the sledge. After a 'night's' sleep they set a direct course for Cape Walker and arrived at the old campsite there (and camped there again) at 5 a.m. on 24 May. Browne checked the cairn but found that no orders had been left for him.

Heading north back to Griffith Island, at 11 p.m. Browne and his men 'observed some dark object on the floe, a long distance off, which were at first supposed to be seals, but which proved to be a travelling party under command of Mr. Krabbé' (Browne 1852: 73). Krabbé was making his second trip to Cape Walker with provisions for Ommanney and Osborn but also for Browne and his men: 'not the least welcome was some preserved milk and extra tea, which is a great luxury to persons in our situation' (Browne 1852: 73). Both parties pitched their tents and chatted for a couple of hours over lunch.

Thereafter Browne and his men made steady progress northward, assisted by a strong wind and the sail: the men could barely keep up. The sledge tracks of the various other parties also represented an aid to navigation when it started snowing and blowing. By 10 p.m. on 27 May they had reached the notorious belt of pressure ice between Griffith and Somerville Islands and then, having negotiated this barrier, in the early hours of 28 May they met a sledge party led by Mecham, like Krabbé making a second trip to Cape Walker with supplies for Ommanney and Osborn. At 4 a.m. they had reached the northwestern point of Griffith Island, to find a shooting party under Lieutenant Bertie Cator, camped off the point. Browne and his men themselves camped for the 'night' some 90 minutes later.

Getting under way on the evening of 28 May, they sighted the ships at 8.30 p.m. and by 11.30 were back aboard Resolute, having been met and welcomed by Captain Austin and a group of officers.

In his 'Remarks' appended to his report, Browne makes a very significant comment about the ice in Peel Sound: 'Taking into consideration the state of the ice in this strait, I must say that it is my opinion that this channel is rarely, if ever, sufficiently open for the purposes of navigation' (Browne 1852:75).
Browne and his men had travelled a total distance of 349 nautical miles $(646 \mathrm{~km})$.

\section{Main party continues southwest}

Two hours after Browne and his men had started from Cape Walker to explore and search the western shores of Peel Sound the other five sledges, led by Ommanney, himself, set off westwards; they found that the massive belt of pressure ice bordering the shore continued well to the west, and they alternated between travelling along the beach (where, however, the snow was deep and the terrain quite rough), and out on the sea ice, beyond the belt of pressure ice.

Having covered about 8 miles they pitched camp at 5.30 a.m. (on 25 April) in the lee of some massive grounded hummocks. Shortly before this Ommanney slipped in crossing a tide-crack and was wet to the knees. And when one of the men, Privett, was changing his boots he found one of his big toes badly frozen; several of the other men were also frost-bitten on faces, toes and fingers.

Since the sky was clear Ommanney got up at 4 p.m. to take sights and was delighted to observe a spectacular parhelia, the details of which he described in full. He also reported the apt and perceptive remark of one of the men: 'When them 'ere sun dogs shows themselves we always gets double allowance from Jack Frost' (Ommanney 1852: 35).

Before getting under way, still heading southwest parallel to the coast, Ommanney reminded everyone to be extra careful in wrapping up their feet to avoid frostbite. Hamilton and Ede were sent ashore to travel parallel to the sledge convoy, looking for any signs of the missing expedition. By 9.30 p.m. the temperature had dropped to $-22^{\circ} \mathrm{F}\left(-30^{\circ} \mathrm{C}\right)$ and hence, in view of the danger of frostbite Ommanney ordered an early stop for the 'night'. By the time the tents were pitched the temperature had dropped to $-26^{\circ} \mathrm{F}\left(-32^{\circ} \mathrm{C}\right)$. Hamilton and Ede returned to report that the land was low and snow-covered and sloping so gradually that it was difficult to identify the actual coastline. In Ommanney's words: 'a most uninteresting, dreary coast.' No signs of the missing expedition had been found.

Although wrapped as warmly as possible in their sleeping bags and wolf-skin blankets, nobody could sleep due to the cold. 'After grog, singing was commenced; example followed in the other tents' (Ommanney 1852: $35)$; this continued for several hours. In view of the severe cold Ommanney decided to switch to travelling during the day as long as the cold lasted.

Therefore next morning (26 April) everyone was roused out at $6 \mathrm{a} . \mathrm{m}$. and all the sledges were on the move by 7 a.m., travelling parallel to the coast, about $11 / 2$ miles $(2.2 \mathrm{~km})$ outside a belt of grounded hummocks. By this point the red sandstone of Cape Walker had given way to limestone (Osborn 1852b: 92). Lt. Osborn was sent to walk the beach parallel to the sledges, and in the afternoon Ommanney and Mecham took his place. 
After negotiating the coastal belt of pressure ice, where the hollows were filled with deep snow, they found the land covered with deep snow, too, that is it represented no improvement over travelling on the sea ice. They climbed a low hill, roughly 80 feet $(24.4 \mathrm{~m})$ high, inland of Krabbé Point, and 'observed Lowther Island bearing N.N.E. and an undiscovered island very low and flat [Hamilton Island] W.N.W. about nine miles' [14.4 km] (Mecham 1852a: 57).

The following night was bitterly cold, $-40^{\circ}$ (F. and $\mathrm{C}$ ), or even colder since the mercury was frozen in the thermometer. Hamilton estimated the temperature dropped to $-44^{\circ} \mathrm{F}\left(-42^{\circ} \mathrm{C}\right)$. In Ommanney's words: 'No sleep; everything frozen in interior of tent and covered with frost' (Ommanney 1852: 36). To allow the air to warm a little once the sun had risen higher he delayed the start next morning until 8 a.m. by which time the temperature was a torrid $-34^{\circ} \mathrm{F}\left(-36.7^{\circ} \mathrm{C}\right)$. It was a clear, sunny morning, with considerable refraction and perhaps due in part to this Lowther Island was still clearly visible to the northeast. In the afternoon Ede and Hamilton walked the shore line, where they saw numerous fox and hare tracks, but no sign of the Franklin expedition. The evening meal was enhanced by the addition of hot coffee, 'a most enjoyable and warming drink under the circumstances' (Ommanney 1852: 36).

On 28 April, once again, Ommanney postponed starting to allow the temperature to rise a little. Ede advised that two men who were severely frostbitten should return with him and his sledge (Inflexible) which was scheduled to start back for the ships in any case. The invalids were Edward Privett (of Ommanney's crew) and George Francis of Hamilton's sledge, Adventure. Their places were taken by Francis Dow and William Caldwell of Ede's crew. Having transferred provisions to the other four sledges, leaving himself with 10 days' supplies for the trip back to the ships, Ede set off at 10 a.m, having 'exchanged shovels with True Blue and tent brush with Succour' (Ede 1852: 79) and to the cheers of the other crews.

\section{Ede and party return to the ships}

Ede set a course straight back to Griffith Island to the northeast. Already that afternoon he could see Young, Davy and Garrett islands, but not Lowther Island. Next morning his detailed description of how he dealt with the cases of snow-blindness is as follows: ' . . . dropped opium into the men's eyes, which were better this morning. Immediately on encamping, those who complained of their eyes were put into their bags at once, and a handkerchief bound over the eyes to prevent the light reaching them as much as possible; and in the daytime, being placed second at drag-ropes they had no occasion to use their sight in finding the way' (Ede 1852: 79).

When they stopped for the night on 30 April Cape Walker and Lowther, Young and Davy islands were all in sight. Soon thereafter a gale blew up on the evening of 2
May, with almost blizzard conditions and in light of this 'and Privett's foot not being quite so well, we kept the tent for the day. The whole of the coverings wet from the mildness of the weather. 36 hours in tent' (Ede 1852: 80).

By the morning of 5 May they were only about 14 miles $(22.4 \mathrm{~km})$ from the ships and the men were keen to try to reach the ships that day. But since he knew there was a difficult belt of hummocks to be negotiated Ede decided to go ahead, reconnoitering a route through the hummocks, then to carry on to the ships and to send a party back to help his crew on this last lap. He reached the ships at 12.20 p.m. and was met by Captain Austin and the officers of Assistance who came out to meet him. A party was immediately sent off to assist his sledge crew and they reached the ships at 5.30.

Ede and his men had covered a total distance of 175 nautical miles $(324 \mathrm{~km})$. His general remarks on the men's health are quite informative:

The men started in good health and spirits, and notwithstanding the severity of the weather pushed on with eagerness. The frostbites which required three of the men named to be sent back to the ship were occasioned by the sudden and severe change which took place a few days after starting, and by the want of covering for the feet, from the small size of the canvass boots allowing only one pair of blanket wrappers to be used. The men walked in their canvass mocassins with as much woollen clothing to their feet as the mocassins would allow, and no other case occurred. The slight cases of snowblindness yielded easily, and in a short space of time, to the tincture of opium or the wine dropped into the eyes night and morning. The whole of the men lost flesh, but improved in their general health; and after the few first days consumed nearly the whole of their allowance. The thirst which tormented them at first gradually became less, and the exertion of dragging was then borne without the same amount of perspiration as at first (Ede 1852: 81-82).

\section{Continuing further southwest}

Following Ede's departure Omanney and the remaining three sledges set off along the coast, S.W. by W. but soon ran into very rough pressure ice. The crews were frequently 'obliged to come to a standing pull with the sledges, rousing them through deep hollows of snow and rough ridges of ice' (Ommanney 1852: 37), “ “one, two, three - haul" being the constant cry all day' (Hamilton 1852: 106). They covered only $2(3.2 \mathrm{~km})$ miles in 4 $1 / 2$ hours, the men suffering from the sun's glare off the snow and exhausted by the endless severe effort. In the meantime Mecham and Hamilton had been walking the shoreline and reported easier travelling there.

Therefore next morning (29 April) Ommanney shaped a course towards the shore, but made only slow progress through the pressure ice. In the bright sunshine everyone found the glare off the snow very trying and 
although most of the men were wearing crepe veils as eye-protection, several began to suffer from snowblindness. Osborn was one of the worst cases, and was effectively blind by the end of the day. On the positive side the temperature at noon was only $-2^{\circ} \mathrm{F}\left(-18.9^{\circ} \mathrm{C}\right)$ in the shade and Ommanney was able to enjoy his lunch outside the tent, sitting in the sun. They reached the beach at 1.45 p.m., but found that as a sledging route it was no great improvement over the sea-ice due to the deep snow. By the time the party stopped to camp (at 6.30 p.m.) they had covered only 8 miles $(12.8 \mathrm{~km})$ during the day and the men were complaining of pains in their shoulders, quite apart from the eye problems. In view of this, Ommanney decided to make the following day a rest-day.

In Ommanney's entry for 29 April there occurs his first reference to the fact that the convoy of man-hauled sledges was accompanied by a dog-sledge: 'Dogs got entangled some distance off, and dropped a case of pemmican; Dore went back for it; returned tired and snowblind' (Ommanney 1852: 37). No further detail is provided in any of the reports.

One of Ommanney's first tasks on the morning of 30 April was to make a survey of the men's health, checking at one tent after another. The results were as follows: four men (including Osborn) snowblind in both eyes; a further 9 men snowblind in one eye, or only slightly snowblind; 2 with sore faces from frostbite or sunburn; 1 case (Thomas Armstrong) with severe diarrhea and general debility; and 1 case John Baily (R.M.) with a severely frostbitten toe. The antidote to the snow-blindness was drops of wine of opium, along with heavy bandages.

Since they had now covered 100 miles $(160 \mathrm{~km})$ from the ship, Ommanney decided to take advantage of the rest day to leave a depot with ten days' provisions here, about 60 yards $(55 \mathrm{~m})$ from the beach. The cases were buried, although the men were unable to dig deeper than 18 inches $(45 \mathrm{~cm})$ in the frozen ground, and were then covered with heavy rocks. A cairn about 7 feet $(2.1 \mathrm{~m})$ high was built on either side of the depot and another 100 yards $(91 \mathrm{~m})$ up the hillslope behind. The test to see whether the cairns would be safe from bears was to observe that 'the dogs, after smelling about for some time, left the cairns, apparently satisfied that there was nothing in them' (Hamilton:1852: 107). This was at Cape Grant, the western tip of Russell Island. After lunch, accompanied by Mecham and Hamilton, Ommanney climbed the hill to get a general view of the coast. What he saw was the coast swinging south for 5 miles $(8 \mathrm{~km})$ into the mouth of an inlet about 5 miles wide, and then running southeast for at least 13 miles $(20.8 \mathrm{~km})$, as far as he could see. This was in fact the western entrance to Baring Channel, separating Russell Island from Prince of Wales Island. Ordering Mecham and Hamilton to investigate the inlet further, Ommannney returned to the tents.

His description of the coastal area is as follows: 'Passed traces of hares and foxes. A great deal of snow on the ground. Limestone with occasional pieces of granite.
Patches of moss and grass to be seen' (Ommanney 1852: 38). His remarks about the sea ice as seen from here are very significant: 'The appearance of the ice was unfavourable for navigation along the coast; generally of old formation, that of several seasons, and fixed along the land; the barrier [of pressure ridges] striking off for the low island reminded me of the floes met with by Parry to the westward, and I saw masses which measured 30 or 40 feet [9.1 to $12.2 \mathrm{~m}$ ] in thickness' (Ommanney 1852: 38). The ice 'met with by Parry' was the old, close multiyear ice streaming east through M'Clure Strait from the Arctic Ocean, and, of course this was a continuation of that stream of ice.

In view of the state of the health of many of the party Ommannney decided to stay in camp for a further day, but he dispatched Mecham to explore the 'inlet', that is the western entrance of Baring Channel. Having exchanged William Scarlett and William Mauger from Adventure and George Campbell and Thomas Ward from Reliance for his four snowblind men Mecham set off at 8 p.m. on 1 May (Mecham 1852a: 58), accompanied for the first couple of hours by Hamilton. Back at Cape Grant there was a southeasterly gale blowing, with drifting snow, and it was even worse on the following day. On the plus side, however, the snow-blind patients were recovering. The antidote, bathing the eyes with 'wine of opium', that is a solution of opium in dilute alcohol, was found to be very effective,

There was no improvement in the weather on the following day (2 May) either, and it was another day of rather tedious inactivity: 'Gale continued with great violence; drift very thick; unable to go out of tent; discomfort great; the limited space of the tent having been pressed in by an accumulation of snow. No room to move; limbs aching from lying so long cramped up. Cooking in the tent is increasing the darkness of complexion, being already well covered with dirt' (Ommanney 1852: 38).

The gale slackened in the early hours of 4 May, however. Everyone was out clearing snow from the tents and sledges. Osborn and the other snowblind sufferers were fully recovered. Since they would not be moving again until the evening (Ommanney had decided to revert to travelling at night), he ordered enough snow melted to allow everyone to wash for the first time since leaving the ships.

\section{Hamilton returns to the ships}

It was time for Hamilton's support sledge, Adventure, to start back to the ships and it was decided that in view of Thomas Armstrong's health problems and William Baily's frostbitten, gangrenous toe, they should also return. Hamilton set off at 7.30 p.m. on 4 May. His orders from Ommanney were to search Young Island and the east coast of Lowther Island on the way back.

After following the coast back for the first day Hamilton struck off, out to sea, towards the N.N.E. and on the evening of 5 May passed within about 10 miles (16 
$\mathrm{km}$ ) of Hamilton Island. By the evening of 6 May he and his party were travelling in fog, but were encountering sastrugi which ran from N.W. to S.E., 'showing that the prevailing winds were the same as we had experienced during the winter. From the thickness of the weather I found it of very great assistance in steering my course' (Hamilton 1852: 109).

Hamilton and his crew reached Young Island in the early hours of 7 May, and were pitching camp by 3.15 a.m. While they were having supper a female bear and two cubs approached, but stayed out of gun range. Hamilton had planned to start exploring the island in the early afternoon, but due to the severe glare off the snow postponed starting since four of his men had only recently recovered from snow-blindness. He set off round the north end of the island at 5.30 p.m., accompanied by two men, while his sledge leader and another two men went the other way; the plan was that they would meet on the other side of the island and return across the middle. Hamilton followed the coast for about three hours, but encountering thick fog before he had met the other group, started back across the island and had some difficulty in finding the camp. When there was no sign of the other group by 2 a.m. he set of again in the direction that they had taken. But he found no sign of them, and returned to the camp by 4.15 a.m. The missing men turned up about five minutes later.

Hamilton's description of the island is as follows:

The island must be about 9 or 10 miles [14.4 or 16 $\mathrm{km}]$ in circumference, judging from the time we were walking, and not more than $4[6.4 \mathrm{~km}]$ broad at any part. The south end is narrow, gradually becoming broader towards the northern side. As far as I could judge, it was full of bays and small inlets, heavy hummocks off the north side extending about two miles $[3.2 \mathrm{~km}]$ off shore. The rest of the coast was pretty free from hummocks, except tidal ones. The land is a series of limestone terraces, rising very gradually from the sea; the summit is not more than 60 feet [18.3 m] above the level of the sea. The middle of the island appears to be a kind of sunken plain, covered with deep snow. The men thought themselves on the floe for some time, as not a patch of stone could be seen. There were no grounded hummocks to denote shoal water, though from the appearance of the land, I should have fancied there would have been (Hamilton 1852: 109-110).

When they got moving again, there was a strong favourable wind blowing and they hoisted a sail to take advantage of it; not only did nobody have to haul in their harnesses but two men even had to sit on the sledge to prevent it running away from the others. After a record run of 21 miles in 8 hours and 30 minutes, they had reached Lowther Island. Spotting a cairn they went ashore and camped. The cairn marked a depot that had been left by Mr. Robert Allen on 1 May. Having enough provisions to take them back to the ship, Hamilton did not disturb the depot. Since he had been seeing numerous bear tracks on the ice, he searched the area around the depot very carefully, and was relieved to find no sign of bears there.

Heading off again in the evening of 9 May, for the first two hours Hamilton walked inland, in case there might be a cairn left by the Franklin expedition, while the sledge crew travelled round the shore. He found the bedrock to be limestone, and saw very little vegetation and the tracks of a hare as the only sign of animal life. Back on the shore, he ordered the sledge crew to cut across the bays while he walked round them on the beach. After camping near the north tip of the island, Hamilton's men built a cairn where he left a message. They then headed off almost due east towards Griffith Island.

The men were marching and hauling very energetically throughout the night of 11/12 May, hoping to reach Griffith Island before camping, but they we slowed down drastically in a belt of old hummocks and they had to camp about 4 miles $(6.4 \mathrm{~km})$ from the cliffs at the island's northwest tip at 4.45 a.m. About an hour before that Hamilton experienced what he described as 'an example of the curious effects of optical deception in these regions':

I saw a black object on the floe, some distance off; this I at first took for a bear, although it looked too large; latterly I began to take it for a tent; when we stopped, several of the men looked at it through the glass, and as they agreed with me in thinking it as a tent, I immediately started off for it, looking round repeatedly at my own tent, and comparing the two appearances; I was convinced that I was right, nor was it till I had got within a hundred yards of it that I perceived that it was the shade thrown on a hummock, the indistinct light which prevailed at the time rendering the appearance still more deceiving (Hamilton 1852: 110).

Rounding the northwest cape of Griffith Island in the evening of 12 May, they sighted the ships at 11.45. Hamilton went ahead of the sledge, to be met by Captain Austin,

by whom I was cordially received; his first anxious questions after the health, spirits and conduct of my crew, I was able to answer most satisfactorily to him; his next, after tidings of our missing countrymen, I was sorry not to be able to give an answer to. I then accompanied him to the sledge, when, after inquiring of each man how he was, he complimented them all on their general good conduct, cheerfulness and alacrity they had displayed under all circumstances. We arrived at the ship at 1.30 A.M., where we received a hearty welcome from all hands (Hamilton 1852:110).

The total distance covered by Hamilton and his sledge crew was 155 nautical miles $(287 \mathrm{~km})$.

\section{Main party continues southwest}

At 7 p.m. on 4 May accompanied by Osborn's sledge True Blue, Ommanney and his sledge crew struck camp, 
heading into the mouth of the inlet. An hour later Mecham's sledge (Succour) joined them. He and his men had had to endure the same blizzard conditions as the main party, but had fared less well; at one point the tent had collapsed under the weight of the snow piled against it. He had penetrated 13 miles $(20.8 \mathrm{~km})$ up the 'inlet' to where it changed from a southeasterly trend to an ENE one; here he camped on Mecham Island, separated from Russell Island to the north by a narrow channel. Even from there, however, he had been unable to discern that he was seeing a channel (Baring Channel) and not just an inlet. Having built a cairn and left a message, on the morning of 4 May he had started back to join the other sledges. That night the sun remained above the horizon at midnight for the first time (Osborn 1852b: 93).

The three sledges now headed north and northwest for Dundas Point, the western entrance cape of Baring Channel. Beyond it the coast trended $\mathrm{W}$ by $\mathrm{N}$ to a low point (Cape Berkeley) almost level with the ice, which the sledges cut across. Some measure of how low and featureless this coast is, is the fact that on 5 or 6 May the sledges cut right across the entrance of the major inlet of Reliance Bay without anyone being aware of its existence. Ommanney described the ice off shore as 'Ice as far as the horizon had every appearance of being very old; enormous masses were grounded along the coast; stood upon one which must have been 40 feet [12.2 m] thick' (Ommanney 1852: 39; Mecham 1852a: 60).

\section{Mecham returns to ships}

On the afternoon of 6 May, at Houghton Stewart Point, Mecham's sledge Succour started back, after transferring 36 days' provisions to Ommanney's and Osborn's sledges. On his way back to the ships, on the evening of 7 May, Mecham struck north from the coast and late on the evening of 8 May reached Hamilton Island and spent the next day exploring the island with two of his men. He 'found it about three quarters of a mile each way, standing N.E. and S.W. about 50 feet [15.2 m] above sea level, and principally of limestone shingle and fine gravel with a few blocks of granite. ... No traces of animals were seen, and there was but little moss upon the island' (Mecham 1852a: 60-61).

From Hamilton Island Mecham headed back to Griffith Island, by-passing Young Island. Along the way he and his men saw quite a number of bears: two initially asleep and then another one, all on the afternoon of 12 May; 2 more bears that evening and a badly wounded bear in the early hours of 13 May, and in the early hours of 14 May yet another bear watching a seal hole between the northwest point of Griffith Island and the ships. The ships came in sight at 4 a.m. and the party reached them at 6 a.m. on the same day (Mecham 1852a: 62).

Their round-trip represented a total distance of 237 nautical miles $(439 \mathrm{~km})$.

\section{Ommanney and Osborn continue south}

Meanwhile, back at Houghton Stewart Point, to save weight Ommanney left his dip circle (for measuring the magnetic inclination) in a cairn along with a report. The two remaining sledges then continued their slow progress along this low, dreary coast, consisting of limestone with a scattering of igneous boulders; their route alternated between outside the line of coastal pressure ridges and that along the beach. With the hummocks and deep snow the progress was so demanding that both Ommanney and Osborn joined their men in harness (Osborn 1852b: 93). At Milne Point, where the grounded ice extended a long way off shore the coast swung round to the S.S.W. On the next day's march (evening of 7 May) a strong wind which blew snow in the men's faces forced Ommanney to order a break after only 4 hours travel; they were then weather-bound for some 44 hours. Ommanney noted, feelingly: 'Cramped with the confined space of the tent' (Ommanney 1852: 40).

The two sledges got under way again at 7 p.m. on 9 May, crawling along the same low limestone coast. Ommanney described the grounded ice masses in the shallow bays as "what is termed "haycock ice", or rounded projections of fresh water ice' (Ommanney 1852: 40 ), that is multi-year hummocks, rounded by melting, from which the salt had drained. In the early hours of 10 May the snow in the hollows between the pressure ridges was so deep and the work of sledge-hauling so strenuous, Ommanney reported that once again he 'clapped on with track belt occasionally'. That 'night' they camped near the fairly conspicuous, easily recognisable cone of Ede Point. Here Ommanney left a depot of 5 days' provisions for each sledge. As usual the men built a cairn where Omanney left a report and, to mark it, hung a worn-out pair of canvas boots from a stick.

Next day, in the early hours of 11 May they crossed the mouth of the major inlet of Drake Bay without realising its dimensions; in Ommanney's journal he simply noted 'struck across a bay' (Ommanney 1852: 40) yet another measure of the featureless nature of this low coast. At about this point 'a dark-coloured fox approached us', that is a blue fox, the blue morph of the arctic fox (Alopex lagopus) (Sale 2006: 385). This was the only fox they had seen, although they had seen plenty of tracks.

On the morning of 13 May they reached Cape John Dyer where 'the land trended away to the S.S.E' with some low islands off shore. Ommanney and Osborn found this quite disappointing since they had hoped the coast would continue more westerly towards Banks Island. They camped a few miles beyond, near Harrison Point, the next day, that is in the early hours of 14 May. The two officers headed ashore to climb a hill that Ommanney estimated was 500 feet $(152.4 \mathrm{~m})$ high (in fact 364 feet $(111 \mathrm{~m})$ high) in order to get a view. The weather was clear and to the S.W. 1/2 W., 20 miles (32 $\mathrm{km}$ ) or more away, across the mouth of a 'vast opening' they could see land. This was the Rawlinson Hills, seen 
across the major inlet of Ommanney Bay. On their way back down to the shore where the men had camped in the meantime they saw the old tracks of a muskox and, here and there, some saxifrage and mosses protruding from the snow. Osborn perceptively remarked that 'a lichen of a bright crimson colour appeared on the larger masses of stone' (Osborn 1852b: 94), that is the striking reddishorange ornithocoprophile lichen, Xanthoria elegans.

On the afternoon of 14 May, Ommanney left another depot of 5 days' provisions at the cape, marked by a cairn which was topped by a stick. 'As we had found our guns useless along this desolate coast' (Ommanney 1852: 42) they also left a gun here, in order to reduce weight.

From here the two sledges headed S. $35^{\circ} \mathrm{W}$. across the mouth of Ommanney Bay. It took them $211 / 2$ hours (2 $1 / 2$ marches) to cover the 28 miles $(48.8 \mathrm{~km})$ to the opposite shore. While the tents were being pitched (on the evening of 16 May) the two officers climbed to the top of a low hill some 100 feet $(30.4 \mathrm{~m})$ high to get an overview of the coast and the terrain. Inland they could see three conspicuous peaks, some of the Rawlinson Hills; they also saw 'a beautiful covey of nine white grouse' (Ommanney 1852: 43), that is the rock ptarmigan (Lagopus muta) (Sale 2006: 162-163).

Back at the tents preparations were made for the two sledges separating, Osborn's northwestwards along the coast, and Ommanney's south along the west shore of Ommanney Bay. At midnight Ommanney hoisted the Union Jack and 'took possession of newly discovered land in the name of Her Majesty Queen Victoria' (Ommanney 1852: 43). A survey of the remaining provisions revealed that they could continue travelling for five days before they would have to start back.

\section{Ommanney searches Ommanney Bay}

When the two sledges got under way on the evening of the 17 May it was under unusually warm conditions, $+25^{\circ} \mathrm{F}\left(-3.9^{\circ} \mathrm{C}\right)$, with heavy snow falling. The going was very onerous: deep snow with bad light so that Ommanney's men were 'falling about on the uneven surface' (Ommannney 1852: 43).

All the men found their boots soaked while one man, William Dore, was taken 'very ill; severe pains in head and hands' (Ommanney 1852: 43). Following the 'lunch break' in the early hours of 18 May Dore was unable to move and for his benefit Ommanney decided to delay their departure for five hours. This is an extremely low coastline and on the evening of 18 May, when Ommanney thought he was on the sea ice 'from seeing a few stones above the surface of the snow, found we were actually on the land' (Ommanney 1852: 44), this being the projecting headland of Hollist Point. Ommanney was even misled into thinking that he had reached the head of Ommanney Bay. Dore was still in pain, and for his further benefit Ommanney ordered camp to be pitched again early on the evening of 18 May to allow him to recover. In the meantime he sent out exploring parties in all directions; accompanied by Frederick Brooke, he himself headed west aiming for a hill from which to get a commanding view. But he had badly misjudged the distance; after two hours of hiking across a plain through deep snow, the hill was still a long way off, and he turned back. The other parties found that this featureless plain extended in all directions.

Dore was still in bad condition on 19 May and hence they stayed in camp all day, the others probably equally glad to do so since there was a bitterly cold westerly gale blowing. Before getting started in the evening the men built a cairn and Ommanney left a message and a coin. Then, after about three miles they struck across a bay to a low point, Dean Point. Continuing south, in the early hours of 21 May, Ommanney found the low, featureless coast 'sweeping round to the eastward' (Ommanney 1852: 44). He and his men had reached the head of Ommanney Bay: 'land so low as to be scarcely distinguishable from ice on which we were travelling' (Ommanney 1852: 44).

After they had pitched camp at 5.40 A.M. a NNWerly gale kept them tent-bound until 11.30 p.m. on 23 May. 'All being particularly miserable, issued an extra allowance of grog at luncheon. Narrow limits of tent became more confined by the accumulation of [snow] drift outside; limbs became very painful from the cramped position in which we are stowed; tried to kill time by an odd number of Chamber's Journal (see Note 2) and smoking' (Ommanney 1852: 44-45). On the evening of 23 May Ommanney sent two men to build a cairn and leave a message on a hill, which turned out to be much further away than anticipated.

Getting under way at 11.30 p.m. on that day and heading east, by 2.30 a.m. Ommanney was able to determine that they had reached the head of Ommanney Bay. When they camped at 5.30 he was able to climb a low hill and to reassure himself that it was indeed the bottom of the bay, and that they were now on its eastern shore with an endless plain stretching to the east and south. Before the party went to sleep, to mark the Queen's birthday (24 May) the Union Jack and the Royal Standard were hoisted and an extra allowance of grog was issued.

Before starting northwards that evening the men built a cairn where Ommanney deposited a record and a coin. They got under way at 8 p.m., but there was a further delay. In only his second reference to a dog sledge Ommanney notes: 'The dog dropped a bag of stores off its sledge' (Ommanney 1852:451) and some men were sent back to look for it. While doing so they found a cairn; a pickaxe and shovel were fetched from the sledge and the cairn dismantled. It proved, however, to be an Inuit food cache, although it contained only bones of seals and birds.

Thereafter the slow, tedious northward progress continued, although alleviated somewhat by a welcome rise in temperature. By 11.30 p.m. on 25 May the temperature was $+16^{\circ} \mathrm{F}\left(-8.9^{\circ} \mathrm{C}\right)$, Ommanney noting 'Enjoyed lunch without being benumbed with cold' (Ommanney 1852: 
46). By noon next day the temperature had risen to $+25^{\circ} \mathrm{F}$ $\left(-3.9^{\circ} \mathrm{C}\right)$, but it was accompanied by a strong northerly gale, driving snow in their faces and the party was tentbound from the early hours of 26 until the evening of 27 May, giving rise to Ommanney's comment 'cramped and wearied by the confinement' (Ommanney 1852: 46).

Starting again at 7 p.m., Ommanney ordered the sledge crew to cut straight across a bay from one headland to another while he walked the beaches. As he did so a gull hovered over him at one point, the first he had seen in eight months. As they continued north in thick mist in the early hours of 28 May they unwittingly crossed the mouth of a major inlet, Smith Bay. Ommanney fired at a ptarmigan and winged it, but it ran so fast that he could not catch it.

Late on the evening of 28 May, the party reached the depot on Harrison Point, to find Osborn and his crew waiting for them, to Ommanney's great relief: 'all well, but like ourselves unsuccessful [in finding any traces of the Franklin expedition]; met with an equally uninteresting coast, and detained by gales, like ourselves' (Ommanney 1852: 46).

\section{Osborn searches the shores of McClintock Channel}

When Osborn's crew parted from Ommanney's on the morning of 17 May in the vicinity of Point Gell they immediately found themselves 'crossing long projecting spits of shingle running to the north-east, with grounded ice between ..... Found the travelling across gravel with even a light sledge extremely laborious' (Osborn 1852b: 95). After camping for the night, by 10 a.m. Osborn and his men had reached 'what appeared the extreme N.W. point of the inlet', that is Hawkes Point at the northwestern entrance to Ommanney Bay. But the weather was not cooperating; visibility in heavy falling snow was severely limited; and the coastline 'consists of so complicated a series of shoal beaches as to render progress in the proper direction, during the thick weather, impossible' (Osborn 1852b: 96); having set out on a short reconnaissance from the tent, Osborn had difficulty in finding it again.

But, getting under way again on the evening of 18 May, the party passed Minto Head, the northern tip of this major promontory on the northwest side of Prince of Wales Island and soon found themselves heading S.W. by $\mathrm{S}$. with a belt of old, heavy hummocks parallelling the coast. When a fresh north-northeasterly wind sprang up after midnight they hoisted the sail on the sledge, and were soon making an estimated $31 / 2$ miles $(5.6 \mathrm{~km})$ per hour, with the crew running alongside the sledge. The drifting snow reduced the visibility severely and in the early hours of the morning they stopped for ten minutes to build a cairn to act as a landmark for the return journey. When they camped the crew were 'in great spirits at the rapid and successful march; the novelty of the sledge sailing by itself affording them a topic of conversation until they went to sleep' (Osborn 1852b: 96).
After they had started again on the evening of 19 May, Osborn walked inland and climbed a low hill. Visibility was excellent and his description of the ice in McClintock Channel represents an accurate and informative portrayal of the multi-year ice of McClintock Channel:

From S.W. by W. to north huge masses of ice of every imaginable form and size strewed the frozen surface of what was once a sea, some rounded by the action of thaws, others sharp and angular, as if recently forced up from the level of the floe by some enormous pressure; but in no one direction did I see any appearance of level ice (Osborn 1852b: 96).

The bedrock consisted of limestone, much of it badly shattered by frost action, and with an abundance of fossils, shells etc.

Soon after the party set out on the afternoon of 20 May the coast ahead swung to the S.S.E., in the vicinity of Cape Richard Collinson, or possibly a little further south at Webb Point. To the west Osborn thought he might be seeing the dark loom of land, and decided to head west, out to sea, to check. He found himself working through severe pressure ice 'all of which appeared to have been subject to pressure from N.W., the elevated edges of the blocks of ice all pointing in that direction' (Osborn 1852b: 96). Crossing them was a severe test of the sledge. The weather cleared towards noon and, to Osborn's disappointment he discovered that, rather than the loom of land to the west, he had been seeing a fog bank. He climbed a hummock 20 feet $(6.1 \mathrm{~m})$ high, and, gazing through his telescope he could find no land towards the southwest while to the northwestward, that is across McClintock Channel, he could vaguely see land at an estimated distance of 40-50 miles (64-80 km). This was the coast of Victoria Island or possibly Stefansson Island.

He continued towards the south and southeast aiming for two conspicuous conical hills, near Cape Ackworth, and camped well out on the sea ice. By 6 p.m., the usual time for breaking camp and continuing, a severe gale was blowing, and Osborn was forced to sit it out. In total the party was weather-bound for 48 hours. This became very tedious : 'All the party became much debilitated by confinement to the tent, in which, from the accumulated [snow]drift there was a very limited space for either lying down or sitting up' (Osborn 1852b: 97). On the morning of 23 May, when the gale had eased somewhat, Osborn and some of his men tried to reach the land in order to build a cairn at their furthest point, that is about 8 miles south of Cape Ackworth, but fog and a renewal of the gale forced them to turn back.

At 7 p.m. that evening, having surveyed the remaining provisions, Osborn decided to start back north. Reaching the land, at 11 a.m. he and his men built a cairn, and by 2 p.m. they were back at the point at which they had struck out to sea westwards. By 1 a.m. they had passed Minto Head and were abreast of Hawkes Point, heading E.N.E. across the mouth of Ommanney Bay for the depot at Harrison Point. With a west-northwesterly wind, force 
7, they hoisted sail on the sledge to great effect: 'Men running after the sledge, which merely required to be steered by means of a drag rope, and occasionally one man obliged to sit on the sledge to retard its progress. As the gale freshened it was a novel sight to see our sledge rising and pitching over the snow ridges, like a boat in a sea-way' (Osborn 1852b: 98). At 3 a.m. on 28 May, when they camped for the 'night' the cairn at the depot at Cape Harrison was in sight, and soon after they got under way again that evening they could see Ommanney's sledge approaching from the southeast. They reached the depot at 8.30 p.m., and Ommanney and his men arrived at 11 p.m.

Ommanney's assessment of what they had achieved between them is a mixture of satisfaction and disappointment:

We have accomplished a most satisfactory search, and completed the examination of all the coast within my reach, without meeting a vestige of any European having ever set foot on these shores; and at the same time I am thoroughly convinced that the [Franklin] expedition never approached these shores; there is not a spot to shelter a ship; and from the shoals along the coast, with the old ice adhering to the land, it is a sea seldom, if ever, navigable for ship (Ommanney 1852: 46).

\section{Ommanney and Osborn head back to the ships}

On the morning of 29 May the combined crews dug up the depot and split the provisions between the two sledges. The provisions were found to be intact, although foxes had chewed on a gun cover. In the afternoon 'a substantial cairn, surmounted with a potato case' was built on a hill some distance inland. That evening : 'Turned our backs on this miserable gulf, probably the first and last Europeans ever destined to sight its dreary shores' (Ommanney 1852: 47). Soon thereafter they spotted a fresh seal hole and took the opportunity to sound the depth: $61 / 2$ fathoms $(11.9 \mathrm{~m})$.

On the morning of 30 May they reached the prominent headland of Cape John Dyer (which Ommanney called 'Land's End'), and camped where they had previously in a relatively benign temperature of $-18^{\circ} \mathrm{F}\left(-27.7^{\circ} \mathrm{C}\right)$. When they started again in the evening, on smooth ice with a relatively shallow snow cover they were able to set sails to a fair wind whereby they were able to make about 2 miles $(3.2 \mathrm{~km})$ per hour. But in the early hours of 31 May they found the sastrugi ridges quite slippery and the men were often slipping and falling. The temperature had risen to $+26^{\circ}\left(-3.3^{\circ} \mathrm{C}\right)$, and they found the temperature inside the tent $\left(+48^{\circ} \mathrm{F}\left(+8.9^{\circ} \mathrm{C}\right)\right)$ quite oppressive.

They reached the depot on Ede Point on the morning of 1 June and camped, Here they noticed the first signs of spring: grass and moss, saxifrages and poppies appearing from under the snow, a pool of water, from which 'though much coloured by vegetable matter, was drunk with avidity' (Osborn 1852), and fresh caribou dung.
Ommanney allowed the men to wash, and since it was so warm $+28^{\circ} \mathrm{F}\left(-2.2^{\circ} \mathrm{C}\right)$ they slept with the tent doors open and on top of their blanket bags rather than inside them (Osborn 1852b: 99). In the evening, they dug up the depot, stowed the sledges and rebuilt the cairn in which, as usual Ommanney left a record and a coin.

Thereafter the slow northward progress continued, although in relatively benign temperatures. At 8 a.m. on 2 June the air temperature was $+43^{\circ} \mathrm{F}\left(+6^{\circ} \mathrm{C}\right)$. These warm temperatures were accompanied by southerly winds, however, and soon the men were hampered by deep snow on the ice. By 8.30 p.m. on 3 June they were back at the cairn where Ommaney had left his dip circle and from where Mecham had started back. A small island, almost certainly Hamilton Island, was visible some 15 miles to the northwest. That 'night' they camped in the middle of the entrance to Baring Channel and at 10 p.m. on 4 May they reached the depot on Cape Grant. At 5 a.m. next morning Ommanney, Osborn and their men were delighted to see another sledge party approaching from the east. This was Lt. Mecham again, making his second trip from the ships to Prince of Wales Island. He brought mail, news, provisions (including some 'delicacies for supper' (Ommanney 1852:48) and a small boat or punt, which he had left some distance to the east.

After a 12-hour rest the combined crews dug out the depot, and shared out and stowed the provisions on their sledges while Ommanney was taking astronomical and magnetic observations. Meanwhile Charles Campbell of Ommanney's crew shot two ptarmigan. At midnight Ommanney's and Osborn's sledges got under way, heading east along the coast while Mecham stayed for another 'night' before starting to explore Baring Channel. At 8.30 p.m. on the evening of 6 June Ommanney and Osborn 'passed the punt which Lieutenant Mecham had deposited, well secured by stones heaped round it' (Ommanney 1852: 49). Immediately thereafter the two sledges parted company; while Ommanney's Reliance continued eastwards towards Cape Walker to make further observations, with Ommanney's permission Osborn's True Blue struck northwards, heading straight back to the ships. On the evening of 7 May Ommanney's men set the sail on their sledge to take advantage of a strong southwesterly wind 'under which the sledge ran as fast as we could walk' (Ommanney 1852: 49). And for the camp that 'night' they had the luxury of 'a favorable spot of dry sandstone gravel' on which to pitch their tent. The site was enhanced by a visit by a flock of snow-buntings around the tent.

When they got under way again that evening the sail and a strong southwesterly breeze again assisted their progress. Osborn's sledge was in sight to the north, with Lowther Island beyond. At 5.15 a.m. on 8 May, at the west end of the cliffs of Cape Walker, they enjoyed the luxury of a patch of grass for their campsite. Ommanney climbed the hill behind the tent and could see Osborn's tent some 5 miles $(8 \mathrm{~km})$ to the north-northwest with Young and Lowther islands beyond. He allowed his men 
an extra ration of grog for supper, while two ptarmigan shot by Campbell, with those he had shot earlier, added variety to the menu.

Next morning Ommanney took a walk along the shore to and beyond Cape Walker. As he described the scene

Here summer was appearing; the snow was dissolving from off the land by the heat generated by the dark cliffs. The land is composed of dark conglomerate; masses are continually breaking away from the cliffs, causing deep chasms. ... The site of our old encampment, where we endured such misery, bore a much more favourable aspect now, under the influence of summer sun (Ommanney 1852: 49).

At the cairn he had left earlier he found messages left by Browne on his route back to the ships, and from Krabbé who had made a second trip from the ships to top-up the depot. Beyond Cape Walker he continued to within sight of a 'bay' (in fact the east end of Baring Channel) and the imposing headland of Bellot Point. There were numerous gulls nesting on the cliffs; he shot one and also a ptarmigan. Back at the tent he spent the day making observations.

Leaving Cape Walker on the evening of 9 June was quite a challenge in terms of negotiating the belt of pressure ice just off shore. It involved several 'standing pulls' and in the hollows between the ridges the men were often up to their knees in water. As Ommanney succinctly assessed the situation: 'During the last twenty-four hours thaw has set in and effected a great change' (Ommanney 1852: 50). A long-tailed duck or oldsquaw (Clangula hyemalis) (Sale 2006:124-125) flew over, and when the party stopped for the 'night', that is during the day, they found the heat in the tent oppressive and the surrounding snow melting. Over the next couple of days they made steady progress, despite frequent fogs that resulted in 'some very beautiful fog-bows, in concentric rings, edged with violet tints.' Navigation was facilitated by following their own out-going sledge tracks and even by finding one of their old campsites, recognisable by the garbage they had left.

On the afternoon of 12 June there was a rather amusing incident that, however, might have ended badly:

3 P.M. awoke by the dog barking which proved to be for a bear close to the tent, and soon heard his growl; all roused up in confusion on finding such an unwelcome visitor so near; gun went off by accident; bruin then poked his nose against tent poles, which brought it down on top of the whole party, and left us at the mercy of the beast; as we emerged we got a view of him, an enormous ugly brute, whose curiosity was drawn to a blanket bag and knapsack; in the meantime Campbell got the other gun and wounded him in the fore leg, above the paw, when he retreated, to our great relief. Followed him up with Campbell, and after a chase of a mile (the bear on three legs), he made $s$ stand, under a hummock, at 20 yards [18.3 m]. Put a ball through his shoulder and chest, and left him to die. Returned to tent out of heat and glare. Altogether it was a most ludicrous sight (though the position was anything but agreeable), and afforded us a good laugh. P.M. 5h. went out and found the bear dead; proved to be a brute of great size, and very old; skinned it (Ommanney 1852: 50-51).

At the end of the following day's travel, Ommanney reported that despite having had a hard day's work the men were 'in high spirits at the thought of reaching the ship, and in response to this he issued another extra halfallowance of grog. Next day they were hauling along the south and southeast coasts of Griffith Island, and there saw the first dovekies (Alle alle) (Sale 2006: 262-263) which were nesting in the talus below the cliffs. With a strong southwesterly wind they set the sail on the sledge; even with four men sitting on the sledge, the remainder had to run as fast as they could to keep up. They even enjoyed a shower of rain, while on Griffith Island the land was completely bare of snow. At 1.00 a.m. on 14 June they sighted the ships, and when they were spotted from the ships as they emerged from the pressure ice, all four ships hoisted their colours. They were soon met by Lt. James Elliott of Assistance, followed by many of the crew members and officers of both ships.

Ommanney and his sledge-crew had been away from the ships for 60 days during which time they had travelled an estimated 480 nautical miles, (552 statute miles or $889 \mathrm{~km}$ ). By Ommaney's estimate he and his men had explored 200 nautical miles (230 statute miles or $368 \mathrm{~km}$ ) of previously unexplored coastline. In his summation he expressed a heart-felt assessment of these coasts: 'The shores along which I have explored were so devoid of interest that I believe few travellers ever experienced a more monotonous journey. We had not even the enjoyment of sport [that is hunting], which has under all circumstances proved a source of amusement to the Arctic travelers' (Ommanney 1852: 51-52). What must have been most disappointing, especially given the emphasis on Cape Walker in Franklin's instructions, was that he had found not the slightest sign of the missing expedition.

\section{Osborn's return trip}

Ommanney and his sledge-crew had been preceded by Osborn and his men by two days in their return to the ships. Almost immediately after parting from Ommanney and his crew on the evening of 6 June Osborn's men had set a sail on their sledge and just before they stopped for the "night" they had "had to run for the last hour to keep pace with the sledge" (Osborn 1852b:100).

Although the start of the melt meant that they were often travelling through saturated snow and slush, or even through melt-pools on top of the ice, they made steady progress northeastwards. They saw more wildlife than at any time during the trip - seals, a glaucous gull (Larus hyperboreus), dovekies (Alle alle), ivory gulls (Pagophilus eburnea), a parasitic jaeger (Stercorarius parasiticus), and geese and grey phalaropes (Phalaropus fulicarius) flying north. They saw two bears on the morning of 10 June, but neither came within firing range. But they also 
saw numerous bear tracks. During one march Osborn 'counted the tracks of no less than eleven different-sized bears, and measured the impression left by the fore-paw of the largest one; it was 17 inches [43 cm] long and 11 [28 cm] inches across' (Osborn 1852b: 100).

They were approaching Griffith Island by the evening of 11 June and landed about 2 miles southwest of its northwest tip, where they camped for the night. They got under way at 6 a.m. on the $12^{\text {th }}$, and having rounded the northwest tip of the island they spotted the ships at 9.30. As they approached the ships a number of men came to assist them for the final lap, and they reached Pioneer at noon. Since leaving the ships Osborn and his sledge crew had covered a total distance of $5241 / 2$ nautical miles (971 km).

Osborn has appended a very usual outline of his crew's daily routine, which, with minor variations also applied to all the other sledges:

3.30 p.m. Call the cook. 3.45. Light the fire. 5.20 Prayers; wind the chronometers. 5.10. Breakfast and pipe; follow senior officer's motions for striking tent or otherwise. At 6.30 commence marching. Daily march 9 hours generally, 5 hours before lunch, 4 hours after lunch; when march was rapid not to exceed 15 $1 / 2$ [miles] [24.8 km] per diem. Lunch about midnight; time dependent on the temperature, for making water to drink. Midnight, issue half a gill [0.07 1] of rum. Whilst weather was cold we always pitched in deep snow and banked up well; directly the tent was secured for the day, change boots and blanket socks or mocassins. 6.30. Dinner of pemmican, and half a gill [0.07 1] of rum; pipes. 7. Turn in; and after 8 A.M. no talking.

Every Sunday read a portion of the divine service for the day (Osborn 1852b: 101).

\section{Allen's trip to Lowther and Garrett islands}

Just over a week after Ommaney had started from the ships with his convoy of sledges, on 24 April another party started from the ships. It was led by Mr. Robert Allen, Resolute's Master and his sledge, Grinnell, was hauled by a crew of seven. His instructions from Captain Austin, in general terms, were to leave a depôt of provisions and fuel for 8 men at the southwestern tip of Lowther Island for the various parties returning from Cape Walker and to search Lowther, Davy and Garrett islands. These islands, along with Young Island, were among those discovered by Parry on his way westwards in H.M.S. Hecla and Griper in August 1819 (Parry 1821).

Initially, when they started at 6.40 p.m. on 24 April the men were hauling two sledges between them, the usual runner sledge, and also a flat sledge (that is a toboggan) on which the provisions and fuel for the depôt were stowed. Surprisingly they were hauling firewood for fuel, namely lignum vitae, a dense tropical hardwood, and an appropriate stove for burning it. They were accompanied by an 'Esquimaux dog' (Allen 1852: 242), as a bear- warning system. Less than three hours after they left the ships, the runner sledge broke down. Unloading it Allen's men made temporary repairs, but they proved inadequate and only 15 minutes later the sledge collapsed again. Allen's solution was to pitch the tent, unload the damaged sledge and leaving most of his men at this campsite, to head back to the ships with two men and with the damaged sledge, empty.

At 10 a.m. next morning (25 April) he and the two men started back to the tent with a different sledge, large enough to carry all the load, and with two men to bring the flat sledge back to the ships. After lunch at the tent they broke camp, and were under way with just one sledge by 1.20 p.m. By 3.40 two of the men were complaining of being tired and having sore feet; Allen, evidently quite soft-hearted 'and being desirous not to lay them up' ordered the tent pitched. His comments on the process of preparing supper are quite illuminating: 'It took $11 / 2$ hours to melt the snow for water, and thaw and boil the preserved meat' (Allen 1852: 243).

With reference to breakfast that evening he includes further informative remarks about the domestic arrangements: 'At 6.30 breakfasted off chocolate; very greasy, and flavoured very strongly with preserved meats, the fuel being insufficient to boil water for washing things up; but in this particular we hope to improve' (Allen 1852: 243). One of the men, Robert Moon, who had been sick when they camped and had been unable to eat his dinner, was now greatly improved. When they got under way at 7.20 there was a useful wind blowing so they hoisted a sail - the usual waterproof 'floor-cloth', that is ground-sheet, hoisted on two tent poles. By 5.30 p.m. on 26 April 'the people having been walking at a smart pace in their carpet boots, were tired about the feet and ankles', Allen again took pity on them and stopped to camp.

By breakfast time next morning (6.15 a.m.) the temperature was $-23^{\circ} \mathrm{F}\left(-30.5^{\circ} \mathrm{C}\right)$ and all their boots were frozen hard and 'we had to soften them by putting them between our legs before getting out of the blanket bags.' They reached Somerville Island at 8 a.m. and headed along the shore to the southwest point where Allen had been instructed to pick up a case of pemmican from a depôt left there by R.D. Aldrich, Resolute's First Lieutenant in early October 1850 (Aldrich 1852: 4). Having done so, and seeing that the ice ahead was very rough, and since the men were already struggling to haul the sledge, he cached two days' provisions and fuel and some other items, to make room for the additional weight of the pemmican.

They started for Lowther Island at 10.15 a.m. and experienced a rather strenuous day, as they hauled the sledge over hummocks and through deep, soft snow between them. And to make things worse, having used all the daily ration of fuel for cooking breakfast and dinner they had to go to bed without any tea.

Nest morning, at 2 a.m.:

we were all awoke out of our sleep by the growling of our Esquimaux dog. The cook, who always slept next 
to the tent door, and had charge of the guns, looked out, and seeing two bears within 13 or 14 yards [12 or $13 \mathrm{~m}$ ] of the sledge, he put a ball into the nearest one, which happened to be a cub, and as the old one would not forsake it, she also was soon shot down. In their paunches was some partially digested seal's flesh. Their bodies were very lean, and we only got sufficient fat from them for half a day' fuel. Being already heavily laden, we could not take the skins with us (Allen 1852: 243).

Ice conditions on the following day were possibly even worse than on the previous one, resulting in frequent standing pulls. But at the end of the day the men were all in good spirits although there were two cases of incipient snowblindness, these being Edward Langley and Michael Collins, both of whom were treated with wine of opium. Langley, rather strangely was also suffering from a nosebleed for much of the morning.

By 4 p.m. on the following day (29 April) they reached the zone of pressure ice around the northeast shore of Lowther Island, 'piled in huge blocks all the way in to the beach for at least a third of a mile' [0.5 km]. Unable to immediately find a practicable route through this zone they camped on the sea ice outside it. Once again the men were 'much fatigued, and the soles of my own feet quite tender from walking backwards and forwards to pick the road, and with carpet boots on' (Allen 1852: 244).

Starting westward next morning, at 8.15 they spotted a feasible route through the pressure-ridge zone, but even then reached the shore only by unloading the sledge, and back-packing everything to shore and returning for the sledge. Reaching the northern tip of the island at 9.10 a.m. Allen left a message there, then proceeded west and down the west side of the island. Once again two men, Michael Collins and Robert Moon were snowblind 'having dragged the whole day at the sledge with their eyes bound up. Applied wine of opium to their eyes.'

The party reached the southwest point of the island (where Allen had been instructed to leave a depôt) at 2.30 p.m. on 1 May. Finding that it was an extensive, low, flat point, where anyone looking for a depot might easily miss it, Allen ordered the tent to be pitched, left two men there to make dinner, while he and the remainder of the men headed east to a more prominent point about $11 / 2$ miles $(2.4 \mathrm{~km})$ away. There they buried the depot, built a cairn, and topped it with a bamboo staff from which a red pocket-handkerchief (presumably his own property) fluttered in the breeze. Back at the tent they found a little moss, with which they eked out the firewood 'and were enabled to have some tea.'

At this point Allen decided to switch to a schedule of travelling by night, to reduce the risk of snowblindness, and hence after breakfast sent the men back to their sleeping bags until around 6 p.m. (on 2 May). But as they broke camp the wind got up, with thick drifting snow, and therefore, seeing that it would be pointless to try to travel, Allen ordered the tent pitched again. The party remained here, weather-bound, until 6.15 p.m. on 4 May. During this tedious wait, Allen had another cairn built near the tent, with a notice giving directions to the other cairn with the depôt. Also during this period the three cases of snowblindness had all recovered 'and the party all well, but heartily tired of being cooped up inside the tent' (Allen 1852: 245).

Allen's next objective was Davy Island. This small island had been discovered in late August 1819 by Sir Parry shortly after discovering Young Island. His ships Hecla and Griper were beating their way north past the west coast of Lowther Island, on their way west to Melville Island when, on the morning of 25 August, from Hecla 'Lieutenant Beechey discovered from the crow'snest, a second low island, resembling Young's Island in size and appearance, and lying between three and four leagues to the northwest of it. I gave it the name of Davy Island, after Sir Humphrey Davy, now President of the Royal Society' (Parry 1821: 57). Parry does not indicate whether Beechey was the only person to see the island, or whether anybody saw it from the deck.

From their first campsite after leaving Lowther Island Allen noted 'Lowther and Garrett Islands in sight but not Davy Island' (Allen 1852: 245). When they started again at 5.55 p.m. on 5 May they

Walked towards the assigned position of Davy Island until 7.30 P.M., when the northern horizon cleared up, and I saw the land just open to the westward of Garrett Island, having the appearance of an island. I supposed that what I had hitherto taken for Garrett Island must be Davy Island, and I altered course for it; and it was not till some time after that I found I was mistaken. To have retraced my steps for Davy Island, and to search it, would have cost me two days; and as the remains of fuel (for I could have made the provisions spin out) would not admit of this, I kept on for Garrett Island (Allen 1852: 245-246).

The identity of the land Allen saw 'just open to the westward of Garrett Island' is somewhat problematical, unless it were some part of distant Bathurst Island, possibly refracted, but the critical point is that Allen could not find Davy Island.

They reached Garrett Island, or rather the barrier of grounded, hummocky ice along its southeast side at 8.30 p.m. on 6 May; finding it impassible they headed south and west outside this zone, 'examining the beach from high hummocks by means of a telescope'. One tends to forget that the primary objective of the entire expedition was to search for the Franklin expedition, but this is why Allen was scanning the beach. Finding a potential route through the pressure ice at 9.30 they unloaded the sledge 'and carried the things over by hand through a remarkable pass formed by huge blocks of ice, piled one upon another to a height of at least 40 feet $(12.2 \mathrm{~m})$ on one side and 30 ( $9.1 \mathrm{~m})$ on the other.' Reaching the beach they continued along shore round the south, west and north coasts of the island. Before leaving the island, somewhere near its eastern tip Allen left a record in a cairn on top of a small hill. 
Leaving the island presented the same difficulties as reaching it. Once again they unloaded the sledge, and carried everything through the barrier of pressure-ice by hand, then returned for the empty sledge, wading through knee-deep snow in all the hollows. Their course now lay almost due east (true) back to Somerville Island, sometimes on good, level ice, sometimes through pressure ice and deep snow which involved the 'disagreeable "one, two, three-haul"' of standing pulls.

On the evening of 10 May:

we saw a bear dodging about the hummocks on our left. We were very much amused to see him rearing on his haunches, and peeping from behind his cover. We crouched down between him and the sledge, in the hope that he would make towards us, but suddenly he moved off at a rapid rate (Allen 1852: 247).

Allen and his men reached Somerville Island (or rather the grounded pressure ice on its south coast) near the depôt, at 9.30 that same evening. Leaving the sledge outside the grounded ice zone, they went ashore, picked up the provisions from the depôt and carried them back out to the sledge. They then continued east along the south shore of the island. Heading out on the last lap towards Griffith Island, they camped once more on the ice. By 1.30 a.m. on 12 May they were off the north coast of Griffith Island, within 7 miles $(11.2 \mathrm{~km})$ of the ships. They pitched the tent once more, enjoyed dinner, then continued towards the ships which they sighted at 5.40. A party from the ships came out to meet them and took over hauling the sledge. By 7.40 Allen and his men were back on board.

While covering a shorter distance than the sledge trips of most of the other parties (119 1/2 nautical miles or $221 \mathrm{~km}$ ) Allen's men had to deal with the unusual inconvenience of having to haul firewood and a woodburning stove rather than the alcohol or tallow used as fuel, and much lighter stoves used by the other parties.

\section{Krabbé's second trip to Cape Walker}

The objectives of Mr. Krabbé's second trip to Cape Walker, as outlined in Captain Austin's instructions to him, were fourfold. Firstly, although he did not expand on the source of his concern, he considered it 'expedient that the party under Lieutenant Browne, from which no account has been received since it proceeded to the southward and eastward from Cape Walker, should be met as soon as practicable' (Austin, 1852: 270). Secondly Krabbé was to fix the position of Cape Walker astronomically, and with reference to Griffith Island. Thirdly he was to build a cairn at 'the most convenient and conspicuous part of Cape Walker' and leave a message there. And finally he was to ascertain the depth of water near the shore, although why Austin should want this information is far from obvious.

With a crew of six men and 'with three cheers from all hands' Krabbé set off from Assistance at 8.40 p.m. on 20 May. After rounding the northwest point of the island, he camped at 3 a.m. When he was ready to start again at 4 p.m. on 21 May there was heavy snow and drifting snow; he waited until conditions had improved, and thus did not get moving again until 11 p.m., setting a sail to a favourable wind. By 3.20 a.m. he had successfully cleared the belt of very rough pressure ice extending northwest from Griffith Island, assisted by the fact that he could follow old sledge tracks.

Thereafter his progress towards Cape Walker was uneventful and quite rapid. At 9 p.m. on 24 May, he stopped to drill through the ice to take his first soundings some 5 miles off Cape Walker; the result was no bottom with 37 fathoms [222 feet, or $67.7 \mathrm{~m}$ ] of line. An hour after he and his crew started moving again they spotted another sledge heading towards them, this being Browne's party. When they met at 11 p.m. Krabbé supplied Browne with two cases of milk, $7 \mathrm{lbs}$. ( $3.2 \mathrm{~kg}$ ) of tallow, $4 \mathrm{lbs}$. of limejuice and sugar, in exchange for a hammer, a lead line, cotton for wicks, a sailmaker's palm, needles and twine. Continuing towards the cape Krabbé camped for the night some 500 yards $(457 \mathrm{~m}$ ) from the cape, a location he had selected for his sounding work.

After a 'night's' sleep, leaving one man at the tent to proceed with drilling and sounding, he and the rest of his men climbed to the summit of Cape Walker, to take observations and to build the cairn. They were near the summit by 11 p.m. but the wind rising 'with snow and drift too thick to see the way' they climbed back down and returned to the tent. Back at the tent by 2 a.m. on 26 May they found that the man they had left had managed to get the ice-drill stuck and frozen-in. The only minor success was that Krabbé had managed to shoot two ptarmigan.

When they woke at 6 p.m. the weather was so foggy that they could not even see the cliffs; with a northwest wind, force $7-8$, visibility was so limited that they were confined to the tent all day. By 4 p.m. on 27 May the wind had dropped significantly and by 5 p.m. Krabbé and some of his men were measuring a base-line on the ice while others were cutting the ice-drill out of the ice, Having succeeded in this, they found that the ice-drill was broken, but they were able to take a sounding: 35 fathoms $(64 \mathrm{~m})$ with a rock bottom. Then, moving right inshore they camped at the base of the route they had used for climbing to the summit of the cliffs.

After a 'night's' sleep, at 7 p.m. on 28 May they started the climb to the summit of the cliffs again to build a cairn and to take a round of bearings. They arrived at the summit at 9.40 'and proceeded with cairn. Placed it about 200 yards $(183 \mathrm{~m})$ from edge of cliff, directly over the highest part, ten feet $(3 \mathrm{~m})$ in diameter at the base. Found stones very difficult to raise from the ground, being frozen in' (Krabbé 1852: 273). With the cairn threequarters complete they headed back down to the tent in the early hours of 29 May. Krabbé managed to shoot 2 hares and 5 ptarmigan on the way back down.

That evening, after the usual daytime sleep, the visibility was too poor to return to the cliff-top. Instead Krabbé 
led his men out onto the ice where, since the ice-drill was broken, they started chopping holes in the ice to take soundings. One hopes that they tackled this task in relays. It took them 2 hours 45 minutes to chop one hole. They took soundings (number unspecified) of anywhere from 5 to 18 fathoms. In an area of level ice they found the ice thickness to be 7 feet 6 inches, $(2.3 \mathrm{~m})$ beneath 14 inches $(36 \mathrm{~cm})$ of snow.

It was not until the evening of 31 May that the weather improved sufficiently to allow them to climb back to the summit of the cliff, and by 12.30 a.m. Krabbé's impressive cairn was complete: 10 feet $(3 \mathrm{~m})$ in diameter at the base, 4 feet $(1.2 \mathrm{~m})$ at the summit, $71 / 2$ feet $(2.3 \mathrm{~m})$ high, and surmounted by a bamboo pole flying a Union Jack. Two feet from the top of the cairn Krabbé left a tin box with a medal of Prince Albert and a record. While one is surprised that Kennedy and Bellot were unable to find Ommanney's cairn at the base of the cliff a year later, it is even more surprising that they did not spot Krabbé's impressive structure on the cliff-top.

As Krabbé and his men made their way back down to the tent they saw seven glaucous gulls, and Krabbé suspected they were nesting. Back down at the ice they moved camp back to the point where they had earlier set up a base-line.

From that campsite Krabbé pursued an ambitious programme of sounding, ambitious in that each sounding involved chopping through the ice, at distances of between half a mile $(0.8 \mathrm{~km})$ and 5 miles $(8 \mathrm{~km})$ from shore.

While lunching in the tent at 1 a.m. on 3 June:

observed a young bear eating pemmican from off the sleigh. Fired from the tent. Shot took effect over left eye, taking the eye and a piece of skull with it. Bruin then fell, apparently done for; but on approaching him he got up and ran off full trot. A shot I sent after him broke his hind leg. He still trotted faster than we could; and a third shot, which passed through his neck, sent him off full gallop, but with great loss of blood. He at last took to the beach and lay down. A fourth shot then passed through his heart; he ran twenty or twenty-five yards, [18 to $23 \mathrm{~m}$ ] and then fell and expired. It was apparently a two years old bear, not long separated from its dam, five feet ten inches in length from nose to end of tail. He produced, when skinned, only about $2 \mathrm{lbs}$. or $3 \mathrm{lbs}$. of blubber, and that of very little use (Krabbé 1852: 274).

At 7.30 p.m. on 3 June Krabbé and his men started back north, and made excellent progress. When they stopped for lunch at 11.30 p.m. on 6 June they spotted another bear approaching:

Remained quite quiet till at thirty yards distant; then, preparing for a shot, the bear instantly stepped out towards us. Put a shot under his fore leg. He fell, and then, with the fore part of his body paralyzed, and with head resting on the floe, pushed himself along about eighty yards $[73 \mathrm{~m}]$ with his hind legs! He then fell and expired. Afterwards proved that the ball had just scored the heart. It was a male. Length from nose to tail in a straight line, seven feet seven inches [2.3 $\mathrm{m}]$. Apparently very old, and scarcely a bit of blubber on it. Left it on the floe (Krabbé 1852b: 275).

By 3.30 a.m. on 7 June they were passing the northwest point of Griffith Island, and, after camping once more, at 2 p.m. they passed the northeast point of the island and saw the ships hoist their colours to show that they had been spotted. A party came out to the meet them, and took over from Krabbé's crew at pulling the sledge. They were back at the ship by 4.30 p.m.

On this second trip Krabbé had managed to shave some distance off his route, as compared to his first trip, reducing it to $1101 / 2$ nautical miles or $205 \mathrm{~km}$.

\section{Mecham's second trip to Cape Walker and Baring Channel}

Exactly a week after Krabbé started his second trip, on 27 May, Mecham also set off southwards on his second trip to Cape Walker, with the sledge Russell. As in Krabbé's case he was to provide assistance to Ommanney's, Osborn's or Browne's teams, if required, to take observations and to take soundings. In case the returning sledge crews encountered wide leads or even open water areas he was also to transport a small wooden boat south, and to leave it where these parties could not help finding it.

Mecham and his men set off from the ships at 6.30 p.m., assisted by some of their shipmates until 9 p.m. Captain Austin also accompanied them until 9 p.m. when he made a short speech before heading back to the ships. Mecham's sledge was also accompanied as far as the northwest cape of Griffith Island by a shooting party led by Lt. Bertie Cator. Mecham and his men stopped at this point for lunch at midnight. Shortly afterwards, at 1 a.m. they came across Lt. Browne's party camped not far from the west coast of Grifffith Island. Mecham and his men camped at 4.30 a.m., and found the tent very hot during the day, to the point that the men were lying on top of their sleeping bags rather than inside them.

Progress south to Cape Walker, and then westwards along the coast of Russell Island was steady, although somewhat marred by snow-blindness, which Mecham treated by bathing the mens' eyes with wine of opium.

On the evening of 4 June, Mecham decided to cache the boat which he had been transporting, near Cape Grey about 12 miles (19.2 km) east of Cape Grant, in a location where Ommanney and Osborn could not fail to spot it:

placed the boat upon the beach in a conspicuous position, bottom up, secured with stones and gravel. Crutches, fearnought [heavy woolen cloth], tallow and nails secured inside; her two skulls [oars] erected at the bow and stern as a beacon. Her position is in longitude $99^{\circ} \mathrm{W}$., and latitude $73^{\circ} 59^{\prime} \mathrm{N}$. by observations, and about 12 miles [19.2 km] from the north-eastern point of the entrance to the inlet [Baring Channel] (Mecham 1852b: 254). 
As he approached the depôt site on Cape Grant at 5 a.m. on 5 June Mecham spotted two tents pitched there already: those of Ommanney and Osborn, heading back to the ships. He and his crew pitched their tent beside the others and Mecham handed over despatches from Captain Austin and also a day's preserved meats for each sledge. Since three of his men were still suffering from snowblindness, Mecham treated them with wine of opium, and let them rest until the morning of 6 June. Ommanney's and Osborn's sledges set off at 2 a.m. on that day, while Mecham's men buried seven days' provisions, marking the location with a staff. They then built a cairn on the hillslope above, also with a bamboo staff, with a painted Union Jack secured to it. His next objective was to examine the 'inlet', running away to the southeast beyond Cape Grant, which he had partially explored in early May; he was leaving the depot at Cape Grant for his return journey, before starting on the trek back to the ships. What he would soon discover was that the 'inlet' was the western entrance to Baring Channel, separating Russell Island from Prince of Wales Island, and that, as a result he would not be coming back to Cape Grant.

At 3.30 a.m. on 6 June, Mecham and his men set off to examine 'the inlet', camping at 6 a.m. When they emerged from the tent at 7 p.m., they found that the snow around the tent had been melting. Heading east, Mecham once again travelled along the inlet between Mecham Island and Russell Island to the north. At one point they went ashore on the island

and found the snow very much thawed and decayed. The soil deep and well covered with grass and moss, which today was ankle-deep in mud, and several small pools. This being the first seen by us this season, it caused considerable excitement among the men, who all drank eagerly of it and filled everything upon the sledge' (Mecham 1852b: 255).

During the day they saw a variety bird species: a glaucous gull, a jaeger, 8 ptarmigan and several flocks of phalaropes.

Having camped, they got under way again at 7.30 p.m. on June 7 th and by 9 had reached the head of the channel on the north side of Mecham Island. Here they encountered some fog, and while negotiating the shallow strait between the east end of the island and Russell Island, they had occasionally to dig through the snow to ascertain whether they were on land or sea-ice. Heading further east along Baring Channel, Mecham stopped at midnight and drilled through the ice to take soundings. While this was going on the fog cleared and he was able to get a clear view down Baring Channel to the east. What he saw was

a fine and picturesque country to the E.N.E., the north shore terminating in a low point, the south in an abrupt headland about twenty miles distant [Cape Hardy]. Between the two there was a large bluff piece of land, which appeared like an island, its northern end terminating in an abrupt headland [Bellot Head], between which and the low point of north shore there appeared to be a clear and open passage (Mecham 1852b: 256).

Abandoning the drilling when he had not reached water with the full length of his drill 7 feet $(2.1 \mathrm{~m})$, Mecham continued east along the channel and camped at 5 a.m. When the party started again at 7 p.m. there was a fair wind blowing and they set the sail to good effect: 'sledge running ahead with one man steering', this despite the fact that the snow was deep and wet 'leaving a pool of water in each footstep'. As they approached the conspicuous ridge ending in the north in Bellot Head, they realised that it was a headland, rather than an island as they had initially thought, and at 2 a.m. pitched the tent for lunch on the narrow isthmus joining the ridge to the mainland of Prince of Wales Island. Mecham and one man then climbed to the top of the ridge; around the tent and on the hilltop they found numbers of fresh caribou tracks. From the hilltop they had a clear view of Cape Hardy and, well to the east beyond it, Edgeworth Island. To the north-northeast, about 15 miles $(24 \mathrm{~km})$ away Cape Walker was also clearly visible. Descending to the shore at the north end of Bellot Head Mecham found Browne's cairn and the message he had left, and also some abandoned boxes from the provisions that Browne had dug up from his depôt there. Mecham and his companion then returned to the tent on the isthmus and camped for the remainder of the day.

Given the soft, wet condition of the snow on the ice and the pools of water on the land Mecham was starting to get concerned about the possibility of meeting wide leads and even polynyas on the trip back to the ships. Retracing his steps around Russell Island to pick up the boat he had cached would have meant a substantial detour and in any case, he felt that the boat was too heavy to haul, given the state of the snow. He opted instead to pick up one of the Halkett boats cached at Cape Walker. Breaking camp at 7 p.m. they set off for Cape Walker, assisted by the sail on the sledge. Initially there was quite a depth of wet snow on the ice, but soon this depth decreased 'and the surface of the floe became covered with about six inches $(15 \mathrm{~cm})$ of water, which though unpleasant, was good travelling' (Mecham 1852b: 257). By 5.30 p.m. they were back at Cape Walker and camped by the cairn which Ommanney had left.

In the evening, having dug up one of the two Halkett boats and having left a note to say that he had done so, at 7.30 Mecham and his crew got under way. They negotiated the belt of severe pressure ice along the shore, but then were faced with another obstacle, a fairly wide lead. It had been wider earlier, but had now closed to 6 feet. Even so, as a precaution Mecham ordered his men to unload the sledge and to carry or throw the provisions and equipment across separately. Initially there was thick fog but once it cleared they were in bright sunshine with 'a beautiful treble fog-rainbow to southeastward' (Mecham 1852b: 258).

Mecham was not heading directly back to Griffith Island and the ships, first he headed for Lowther Island, 
intending to search its shores and to survey it. Having camped once en route he and his crew reached the south west point of that island in time for lunch at 1.30 a.m. on 12 June. He luckily spotted the bamboo stick from which Allen's red pocket handkerchief was fluttering, and nearby the top of a depot case peeking out of the soil. Allen's cairn had evidently been destroyed by bears which had also been scratching at the bread case, but had only succeeded in loosening the lid. Mecham's men dug up seven days' provisions and fuel, along with a note from Allen; the bread was somewhat spoiled by getting wet. Walking a short distance to the extreme southwest tip of the island Mecham found Allen's other cairn with his note. As a sure sign of spring, flocks of brent geese (Branta bernicla) (Sale 2006: 98) had been flying over, northwards, all day.

Mecham's next objective was Davy Island, which Allen had been unable to find six weeks earlier, but which Ede had reported seeing on 30 April (Ede 1852: 80). With this in view, on the evening of 12 June Mecham set off steering $\mathrm{W}$. by $\mathrm{N}$. But early in the next march, at 8 p.m. on the next day in thick weather he encountered dreadful conditions:

Arrived at and entered the hummocks. Found the travelling exceedingly bad; several large pools of water, and the sludge so deep that the sledge was frequently buried above the bearers, and no footing for the men. 10 weather very thick. Finding the ice getting worse, and the men unable to get the sledge ahead, as well as the continuation of it as far as can be seen to the westward, hauled the sledge upon a piece of dry ice, and encamped. Midnight, wind fresh from southward, with heavy rain (Mecham 1852:259).

On the evening of 14 June, leaving two men and the sledge at the tent Mecham and the rest started hiking westwards taking their lunch with them. After $21 / 2$ miles travelling conditions became abominable. They would break through a snow crust into water that came over the tops of their sea-boots, and would have to help each other to extricate themselves. From the top of a high hummock they could see Young Island to the south-southwest and Garrett Island to the north, but there was no sign of Davy Island where it was supposed to lie, to the west. It now started to rain heavily and, abandoning his search Mecham headed back to the tent, arriving very wet and tired at 11 p.m.

On the evening of 15 June they broke camp and started eastwards, 'not having been able to get any observations or obtain a view of Davy Island, although by our dead reckoning and bearings we had been within three miles of its position on the chart, and upon the same parallel of latitude by observation' (Mecham 1852b: 259). Just over a year later, in late August 1852 H.M.S. Resolute and Intrepid were back in these waters, temporarily blocked by ice in the vicinity of Lowther Island. George McDougall, Master on board Resolute, reported:

Although the weather during the day was variable, the atmosphere was very clear, enabling us to recognize
Garrett Island and the peaked hills of Bathurst Land [as well as Cape Walker and Young Island]. Vainly, however, we stretched our eyes to discern Davy Island, and from our position, it was decided to be non est (M'Dougall 1857: 99).

Travelling conditions for Mecham and his men had not improved: slush and water so deep that the sledge sank so deep that the men could not move it. Unloading half the load they carried it forward to a smooth floe about 1 $1 / 2$ miles $(2.4 \mathrm{~km})$ ahead, then went back for the sledge. They found an area of dry snow on which to camp, at 3 a.m. on 16 June.

During the next march they rounded the south end of Lowther Island; both there and later in the march they encountered several leads up to 4 feet in width, but fortunately none wider. When they started on the following march, at 7 p.m. on 17 June a fair wind allowed them to set the sail. They encountered a belt of pressure-ice which Mecham suspected marked a shoal area; there were quite a few cracks and soundings revealed that he was correct, the depths steadily decreasing from 15 1/2 fathoms (28.3 $\mathrm{m})$ to 7 fathoms $(12.8 \mathrm{~m})$ before increasing again. It was here that they saw the first Brünnich's guillemot (Uria lomvia) (Sale 2006: 265-266) flying over. After midnight they encountered good, almost snow-free ice again and with the sail set, only one man was needed to stay with the sledge to steer it.

After camping, when they started again on the evening of 18 June they found the ice covered with water, and as they negotiated the belt of hummocks extending northwest from Griffith Island, they found the water very deep among the hummocks. Then, in the early hours of 19 June they found the water 'so deep that the men could get no footing, or make any progress with the sledge, it being buried above the bearers. Men wet through, and no place we could encamp' (Mecham 1852b: 260). Mecham's solution was to lash the load on the sledge securely then leave the sledge, with the sledge ensign flying over it, then, with each man carrying his knapsack, they started off for the ships on foot.

Halting on the beach under the northwestern cliffs of Griffith Island, Mecham issued a ration of grog, then they rounded the north end of the island. They sighted the ships at 6 a.m. Leaving two men to assist William Mitchell who was complaining of severe back pain, Mecham and the remainder struck out for the ships, wading through deep water on the ice for the entire distance. They reached Assistance at 8 a.m. After waiting for a week, by which time most of the water had drained off the ice, on 27 June, with the same crew of men, Mecham went back to retrieve the sledge.

In total, on this second trip Mecham and his sledge crew had covered a total distance of 238 1/2 nautical miles $(442 \mathrm{~km})$.

\section{Conclusion}

The sledge crews involved in this campaign, led by Ommanney, to search the area southwest of Cape Walker, 
had hauled their sledges for a remarkable total distance of 2508 nautical miles, or $4645 \mathrm{~km}$, overcoming chaotic pressure ice, deep snow, bitter cold resulting in frostbite, snow-blindness and frequent periods of low visibility. They had not found even the slightest trace of the missing Franklin expedition, but they, or their officers, had mapped all the coastlines within a remarkable total area of $17,769.6$ square nautical miles, or $60,941 \mathrm{~km}^{2}$.

Ommanney's conclusion as to the potential of what would later be named McClintock Channel as a shipping route is very significant: '... from the nature of the ice it is impossible to say what time the oldest may have taken to accumulate and acquire its thickness. Generally speaking, most of it has been permanently fixed to the shores for many seasons, consequently I entertain no hope of ships ever reaching the continent of America S.W. of Cape Walker' (Ommanney 1852: 51). In short Erebus and Terror could not have come this way. On the other hand, Browne's equally negative assessment of the navigability of Peel Sound was erroneous. Admittedly Sir Allen Young, in Pandora would find it blocked with ice somewhat further south than Browne's furthest point in 1875 (Young 1876), but this was the route by which Amundsen penetrated south to King William Island in Gjøa in 1903. Moreover, in light of what is now known as to where Erebus and Terror ended up, that is off the northwest or southwest coasts of King William Island, they must have travelled south down Peel Sound between Prince of Wales Island and Somerset Island. One has to assume that ice conditions must have prevented Franklin from leaving a message on Cape Walker as they passed. If it were accessible, his failure to leave a message there, given the stress on Cape Walker in his instructions, is perhaps even more incomprehensible than his failure to leave a message as to his future movements at Beechey Island.

Given this demonstrable variability in ice conditions in Peel Sound from year to year, it is quite possible that it was navigable in 1852. In that year, a squadron of five ships, namely the same four ships as those of Austin's squadron in 1850-1851, plus H.M.S. North Star, under overall command of Captain Sir Edward Belcher, were dispatched by the Admiralty to continue the search. The critical sentences in Belcher's instructions read as follows:

Arrived at this point [Beechey Island] two great objects will engage your attention:

$1^{\text {st }}$. The endeavouring to pass up Wellington Channel with one sailing vessel and one steamer.

$2^{\text {nd }}$. The advance of a similar force towards Melville Island (Great Britain 1852:1).

There is conspicuously no mention of Cape Walker, which had featured so prominently in Austin's instructions, or of any other possible objective to the south. Influenced by Ommanney's, Osborn's and Browne's reports, the Admiralty had evidently decided that Franklin could not have headed south by the channels which they had investigated, and that there was therefore little point in ordering Belcher to investigate them. Belcher complied with his instructions to the letter and no vessels were sent to reconnoitre either McClintock Channel or Peel Sound. While the former was almost certainly still blocked with heavy multi-year ice in 1852, 1853 and 1854, it is quite possible that Peel Sound may have been partially or wholly open, and hence navigable in one of those years. If so, and if one of Belcher's ships had investigated it, it is not inconceivable that all the evidence as to the fate of Franklin's expedition discovered by McClintock in 1859, might have been discovered five years or more earlier.

One intriguing aspect of the sledge journeys made by Ommanney and the leaders of his support sledges is the remarkable number of cairns built, and in most of which messages were left. The total number is at least 20, and the messages provided information as to the date, the identity of the sledge leader and of the ship from which the party had come, and the intended destination, or at least the direction in which the party was headed. One wonders as to the intended purpose of these messages. If they were intended as a 'safety net' for the sledge parties, it seems inconceivable that any of the sledge parties would have encountered such serious problems that none of its members would have been able to return to the ships. And even if that were the case, by the time that party failed to return to the ships and a search-and-rescue party was dispatched, break-up of the ice would probably have rendered travel by either sledge or boat impossible. Another possibility is that they were intended to demarcate the area covered by Ommanney's two formal ceremonies, claiming the area for Queen Victoria.

The true explanation is that Ommnaney and the other sledge party leaders were simply obeying instructions, at least to some degree. It is noteworthy that Franklin had received no such instructions. While he had been instructed that 'you do frequently, after you have passed the latitude of $65^{\circ}$ north, once every day when you shall be in an ascertained current, throw overboard a bottle or copper cylinder closely sealed, and containing a paper stating the date and position at which it is launched' (Great Britain 1848a: 6), nothing was said in his instructions about leaving messages on land.

Even before the astounding lack of any messages left at Beechey Island had become known, somebody at the Admiralty must have realized that there had been a serious omission in Franklin's instructions. To correct this the instructions to Austin specified that:

You will take the utmost care in leaving memorials of your track in the usual manner, and in every prominent place, and enjoin the same precaution upon all the ships and land parties detached from you or them (Great Britain 1850: 5).

In compliance with these instructions Austin's orders to Ommanney stated that 'I wish one of the printed notices with which you are supplied deposited each day near your encampment' (Great Britain1852: 23). Ommanney sensibly decided that this instruction was clearly 'over the top' in terms of the number of messages that this 
would have involved, quite apart from the fact that many of them would have to be left on the sea ice, and would be very likely to be covered with snow, and would probably have disappeared by the end of the summer. Hence the 20 cairns and messages which he and his support officers left on land represented a slightly more sensible compromise.

A minor but significant result of Ommanney's sledging campaign (and of Allen's trip to support it) was the conclusion, confirmed by McDougall's observation a year later, that Davy Island did not exist. It seems likely that Beechey, who, as reported by Parry, was the first to report having seen it, may have been confused by some dirt-laden hummocks, or by a mirage, or a combination of both. Ede was probably similarly misled when he reported seeing the island on 28 and 30 April, on his way back to the ships. It does not feature on any maps produced by Canada's Army Survey establishment, and is listed by the Geographical Names Board of Canada as having been rescinded as of 1 December 1960. Nonetheless, it is shown by a symbol, with its correct coordinates as shown on Parry's map, on Google Maps as of January 2016.

\section{Notes}

1. The Halkett boat, the predecessor of the Zodiac, was an inflatable boat invented by Lt. Peter Halkett, R.N.

Halkett's initial design in the early 1840s was for a boat-cloak, i.e. a cloak of rubberized cotton fabric, the lining of which contained an airtight inflatable oval, divided into four airtight compartments; a pocket contained a paddle-blade and a small set of bellows. When the airtight compartments were inflated the cloak was converted into a rubber boat. A walking stick could be used as the shaft of the paddle. Halkett had successfully tested a prototype over a distance of $15 \mathrm{~km}$ on the Thames in 1844. He then designed a larger version which folded into a backpack which could be easily carried by one man, and, when deflated could be used as a watertight groundsheet. A canvas cover reduced the danger of the boat being punctured. For further details see: Wilson 1955.

A Halkett boat used by John Rae on his various expeditions is preserved at the Stromness Museum in the Orkney Islands, while a second example is held in the Hudson's Bay Company's collection in the Manitoba Museum in Winnipeg, Manitoba.

2. Chamber's Edinburgh Journal, founded by William Chambers in 1832 and with a focus on topics such as history, religion, language and science.

\section{Acknowledgements}

I wish to thank Ms Susan Kooyman, Archivist at the Glenbow Museum, Calgary, for allowing me free access to Ommanney's journal, both the manuscript and a transcript. I am indebted to an anonymous reviewer for a wide range of very useful comments with very valuable additional information, and I also wish to thank Mr. Robin Poitras, Department of Geography, University of Calgary for the superbly drafted map. The addition to the map of the routes of all the sledge parties was contemplated, but given that there were seven sledge parties, several of which returned to Griffith Island by different routes, and that two of them made two separate trips, inclusion of all their routes on the map would make it confusingly cluttered.

\section{References}

Aldrich, R.D. 1852. Letter to H.T. Austin. In: Great Britain. Parliament. Additional papers relative to the arctic expedition under the orders of Captain Austin and Mr. William Penny. Presented to both Houses of Parliament by command of Her Majesty. London: Eyre and Spottiswoode: 3-4.

Allen, R.C. 1852. Journal of proceedings. In: Great Britain. Parliament. In: Additional papers relative to the arctic expedition under the orders of Captain Austin and Mr. William Penny. Presented to both Houses of Parliament by command of Her Majesty. London: Eyre and Spottiswoode: 242-250.

Austin, H.T. 1852. Letter to F.J. Krabbé. In: Great Britain. Parliament. Additional papers relative to the arctic expedition under the orders of Captain Austin and Mr. William Penny. Presented to both Houses of Parliament by command of Her Majesty. London: Eyre and Spottiswoode: 270.

Barr, W. and N. and J.-C. Forestier-Blazart. 2014. 'The last duty of an officer"' Lieutenant de vaisseau Joseph-René Bellot 1826-1853, in the Franklin search. Polar Record 50(252): 130.

Bellot, J.-R. 1854. Journal d'un voyage aux mers polaires exécuté à la recherché de Sir John Franklin. Paris: Perrotin.

Browne, W.H. 1852. Report of the proceedings of the sledge Enterprize, in charge of Lieut. W. H. Browne, Her Majesty's Ship Resolute, commencing $15^{\text {th }}$ April, ending $28^{\text {th }}$ May 1851. In: Great Britain. Parliament. Additional papers relative to the arctic expedition under the orders of Captain Austin and Mr. William Penny. Presented to both Houses of Parliament by command of Her Majesty. London: Eyre and Spottiswoode: 65-75.

Cyriax, R.J. 1939. Sir John Franklin's last expedition. A chapter in the history of the Royal Navy. London: Methuen.

Ede, C. 1852. Journal of her Majesty's Sledge Inflexible, attached as limited party to the south-western searching division. In: Great Britain. Parliament. Additional papers relative to the arctic expedition under the orders of Captain Austin and Mr. William Penny. Presented to both Houses of Parliament by command of Her Majesty. London: Eyre and Spottiswoode: 76-82.

Great Britain. 1848a. Arctic expedition. Return to an address of the Honourable the House of Commons dated 21 March, for: copies of instructions to Captain Sir John Franklin, in reference to the arctic expedition of 1845 .... Ordered by the House of Commons to be printed. 13 April 1848. (Great Britain. Parliament, House of Commons. Sessional papers, Accounts and papers, 1847-48, v. 41, no. 264).

Great Britain. 1848b. Arctic expedition. Return to an address of the Honourable the House of Commons, dated 26 May 1848: for a Copy of the orders from the Lords Commissioners of the Admiralty, under which Captain Sir James Clark Ross has proceeded on an expedition in search of Sir John Franklin. Ordered by the House of Commons to be printed, 7 June 1848.

Great Britain. 1850. Arctic expedition. Return to an address of the Honourable the House of Commons dated 10 May 1850, for: Copies of instructions from the Admiralty to Captain 
Austin and to any other officers in Her Majesty's service engaged in arctic expedition, since the date of the last Parliamentary return, Admiralty, 28 May 1850, J.H. Hay, Chief Clerk. Ordered by the House of Commons to be printed, 31 May 1850.

Great Britain. 1852. Arctic expedition. Return to an order of the Honourable the House of Commons dated 4 May 1852, for: $A$ return of the sailing orders given to Sir Edward Belcher related to the arctic expedition. Admiralty, 6 May 1852. J. H. Hay, Chief Clerk. Ordered by the House of Commons to be printed, 7 May 1952: 104-112.

Kennedy, W. 1853. A short narrative of the second voyage of the 'Prince Albert' in search of Sir John Franklin. London: W.H. Dalton.

Krabbé, F.J. 1852a. Her Majesty's Sledge Success, auxiliary to Captain Ommanney, Mr. Fred. J. Krabbé, Second Master, in command. Journal of proceedings. In: Great Britain. Additional papers relative to the arctic expedition under the orders of Captain Austin and Mr. William Penny. Presented to both Houses of Parliament by command of Her Majesty. London: Eyre and Spottiswoode. 83-87.

Krabbé, F.J. 1852b. Journal of proceedings from $20^{\text {th }}$ May to $7^{\text {th }}$ June 1851 , during a journey to Cape Walker to meet the southern party, fix position of cape, etc. In: Great Britain. Additional papers relative to the arctic expedition under the orders of Captain Austin and Mr. William Penny. Presented to both Houses of Parliament by command of Her Majesty. London: Eyre and Spottiswoode: 272275.

M'Dougall, G.F. 1857. The eventful voyage of H.M. Discovery Ship 'Resolute' to the arctic regions in search of Sir John Franklin and he missing crews of H.M. Discovery Ships 'Erebus' and 'Terror', 1852, 1853, 1854. London: Longman, Brown, Green, Longmans and Roberts.

Mecham, G.F. 1852a. Journal of Her Majesty's Sledge Success, attached as a limited party to Captain Erasmus Ommanney - south-western division. In: Great Britain. Additional papers relative to the arctic expedition under the orders of Captain Austin and Mr. William Penny. Presented to both Houses of Parliament by command of Her Majesty. London: Eyre and Spottiswoode: 53-62.

Mecham, G.F. 1852b. Journal of Her Majesty's Sledge Russell, G.F. Mecham, Lieutenant, commanding. In: Great Britain. Additional papers relative to the arctic expedition under the orders of Captain Austin and Mr. William Penny. Presented to both Houses of Parliament by command of Her Majesty. London: Eyre and Spottiswoode: 252-263.
Ommanney, E. 1850-1851. H.M.S. Assistance, 1850-1851, employed in the search after Franklin's missing expedition. Glenbow Museum Archives, Calgary.

Ommanney, S. 1852. Journal of Her Majesty's Sledge Reliance, Captain Erasmus Ommanney, searching to the southwest of Cape Walker, for the missing expedition under the command of Sir John Franklin. In: Great Britain. Additional papers relative to the arctic expedition under the orders of Captain Austin and Mr. William Penny. Presented to both Houses of Parliament by command of Her Majesty. London: Eyre and Spottiswoode: 30-52.

Osborn, S. 1852a. Stray leaves from an arctic journal; or Eighteen months in the polar regions in search of Sir John Franklin's expedition in the years 1850-51. London: Longman, Brown, Green and Longmans.

Osborn, S. 1852b. Lieutenant Osborn's journal. In: Great Britain. Additional papers relative to the arctic expedition under the orders of Captain Austin and Mr. William Penny. Presented to both Houses of Parliament by command of Her Majesty. London: Eyre and Spottiswoode: 89-103.

Parry, W.E. 1821. Journal of a voyage for the discovery of a North-West Passage from the Atlantic to the Pacific performed in the years 1818-20, in His Majesty's Ships Hecla and Griper ... London: John Murray.

Ross, J.C. 1850. Narrative of the proceedings of Captain Sir James C. Ross, in command of the expedition through Lancaster Sound and Barrow Straits. In: Great Britain. Arctic expedition. Return to an order of the Honourable the House of Commons dated 5 February 1850, for: Copies of any reports or statements from the officers employed in the arctic expeditions ... in respect to the resumption of the search for Sir John Franklin's expedition ..., 58-64. (Great Britain. Parliament, House of Commons. Sessional papers, Accounts and papers, 1850 , v. 35 , no. 107).

Ross, M.J. 1994. Polar pioneers. John Ross and James Clark Ross. Montreal and Kingston: McGill-Queen's University Press.

Sale, R. 2006. A complete guide to arctic wildlife. London: Christopher Helm.

Sutherland, P.C. 1852. Journal of a voyage in Baffin's Bay and Barrow Straits, in the years 1850-1851; performed by H.M. Ships Lady Franklin and Sophia ... London: Longman, Brown, Green and Longmans.

Wilson, C. 1955.Footnotes to the Franklin search. I: Halkett's air boat. The Beaver 285(1): 46-8.

Wilson, M. 1973. Sir John Ross's last expedition in search of Sir John Franklin. The Musk-Ox 13: 1-11. 